\title{
The returns on mining exploration investments
}

\author{
Manuel Regueiro González-Barros ${ }^{(1)}$ y José Antonio Espí(2) \\ (1) Spanish Geological Survey, Ríos Rosas 23, 28003 Madrid. \\ m.regueiro@igme.es \\ (2) School of Mines of Madrid, UPM. Ríos Rosas, 21, 28003 Madrid. \\ joseantonio.espi@upm.es
}

\begin{abstract}
This paper explores the state of the art of the research regarding the returns on the investments in mining exploration from different perspectives. The analysis begins with an introduction to population trends, economic growth and world mining. Then we go through a detailed analysis of the different options for examining the returns obtained from mining exploration: exploration versus deposit discovery, ROI, mining exploration success rate, TSR, exploration costs versus resources found, and mining companies and the benefits from mining investment funds. This review concludes that although ROI analyses are in general negative for mining, nevertheless when an important deposit is found as a result of exploration, ROI becomes highly positive. Besides, there is a consensus in that the greenfield exploration rate of success is from 0.5 to $1 \%$ whereas in brownfields the figure (as expected) rises to $5 \%$. TSR studies indicate that mining indexes can reach return rates of $17.5 \%$ in some periods and negative rates with respect to other indexes, clearly highlighting its very cyclical nature. The case we present for the returns for gold exploration in Australia shows high benefits for mining companies, but, in general gold deposits with processing costs over 1,000\$/ounce can produce losses. In any event, the overall results of the main global mining companies show long periods with benefits intercalated with short periods of high losses, which again highlights the cyclical character of the global mining business. Investment funds advocating mining show similar behaviour. We also show the future of the world mining sector from different prospective studies which suggest that mining will no doubt survive to due to its cyclical nature. In this respect we will see a more sustainable consumption of mineral resources in a more sustainable world, which will also see an increment of recycling within the framework of the new circular economy. However, all this will only happen if adequate infrastructures, regulatory framework and competitive costs are provided by the social, economic, and industrial stakeholders. Technology will be a decisive key factor in the future, as will be a better understanding of the supply chains and client preferences.
\end{abstract}

Keywords: exploration, investments, mining, returns.

\section{El retorno de las inversiones en exploración minera}

\section{RESUMEN}

El presente trabajo explora el estado del arte de las investigaciones sobre el retorno de las inversiones en exploración minera desde todos los puntos de vista. Se hace primero una introducción a las tendencias en población, crecimiento y minería mundial. Después se hace un análisis pormenorizado de las posibles maneras de analizar el retorno obtenido en la inversión minera: exploración frente a descubrimientos de yacimientos, el retorno sobre la inversión (ROI), la ratio de éxito en la investigación minera, el retorno para los inversores (TSR), los costes de la exploración frente a los recursos localizados, los beneficios de las empresas mineras y los fondos de inversión minera. El estudio concluye que, por un lado, los análisis ROI son en general negativos para la minería, pero cuando, como resultado de la investigación, se descubre un yacimiento importante, el ROI es excelente. Por otra parte, la ratio de éxito en la minería de zonas vírgenes está entre el 0,5 y el $1 \%$, y en zonas conocidas es de un $5 \%$. El estudio delTSR indica que los índices mineros pueden tener tasas del $17,5 \%$ en unos períodos y tasas negativas frente a otros en otros, lo que remarca su marcada ciclicidad. El caso de los retornos de la exploración del oro en Australia indica grandes beneficios para las empresas mineras, pero en general, para yacimientos con gastos de tratamiento superiores a 1000\$/onza se pueden producir pérdidas. En todo caso los datos de las principales empresas mineras mundiales indican largos períodos de beneficios intercalados con períodos más cortos de grandes pérdidas, lo que vuelve a demostrar el carácter cíclico del negocio minero mundial. Los fondos de inversión dedicados a la minería tie- 
nen un comportamiento similar. Finalmente se analiza el futuro del sector minero mundial a partir de diferentes estudios prospectivos, que concluyen que sin duda la minería sobrevivirá a su naturaleza cíclica, pero habrá un consumo más sostenible de recursos en un mundo a la vez más sostenible que verá un aumento del reciclado en el marco de la nueva economía circular siempre que se le proporcionen las adecuadas infraestructuras, marco regulatorio y una economía de costes competitiva. La tecnología será un factor decisivo en el futuro, igual que entender mejor las cadenas de suministro y las preferencias de los clientes.

Palabras clave: exploración, inversiones, minería, retornos.

\section{Introduction}

Mining is a global business, and though sometimes despised and sometimes glorified, there are no alternatives today that can supply the whole world with the raw materials it still needs and will continue to need in the coming years.

The reason that sustains such a statement does not come from governments, politicians or mining companies themselves, it lies in the increasing number of raw material users that populate the world, and in this respect demand drives the mining business.

Figure 1 shows the population growth from 1750 to nowadays (7.55 billion) and the predicted world population in 2100 (11.2 billion).
Population predictions suggest that over the next two decades the world will have another two billion inhabitants and, as the following graph indicates, it is expected that around three billion people will join the middle classes. At the same time another billion more will still live without the basic supply of electricity, modern cooking fuels, and safe and reliable access to food and water.

Thus an increasing population alone would not generate demand, unless the global economy grows and predictions also point to a steady growth in world GDP (Fig. 2).

But there are other factors apart from income growth and world population, such as technological advances, changes in the environment and in the

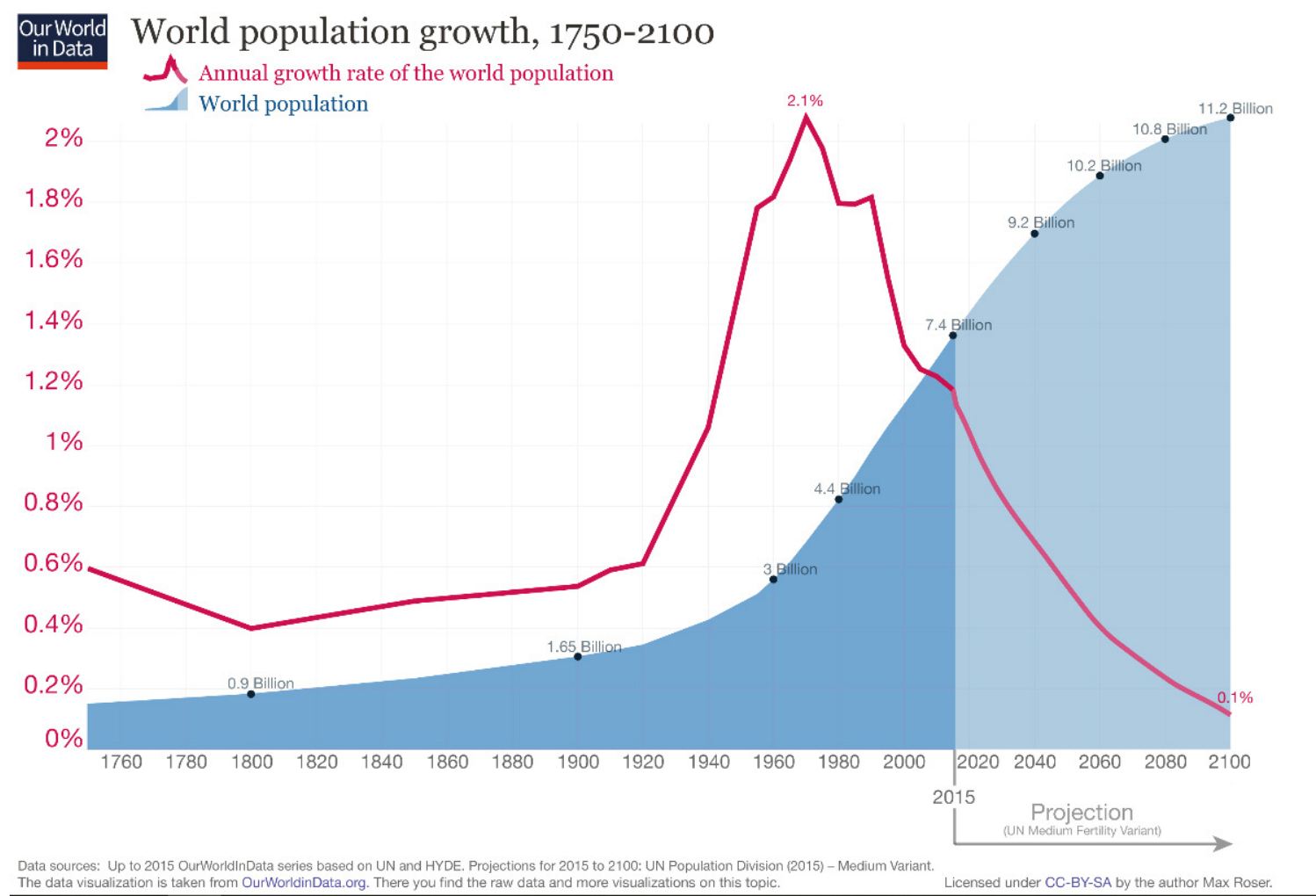

Figure 1. World population trends.

Figura 1. Tendencias de la población mundial. 


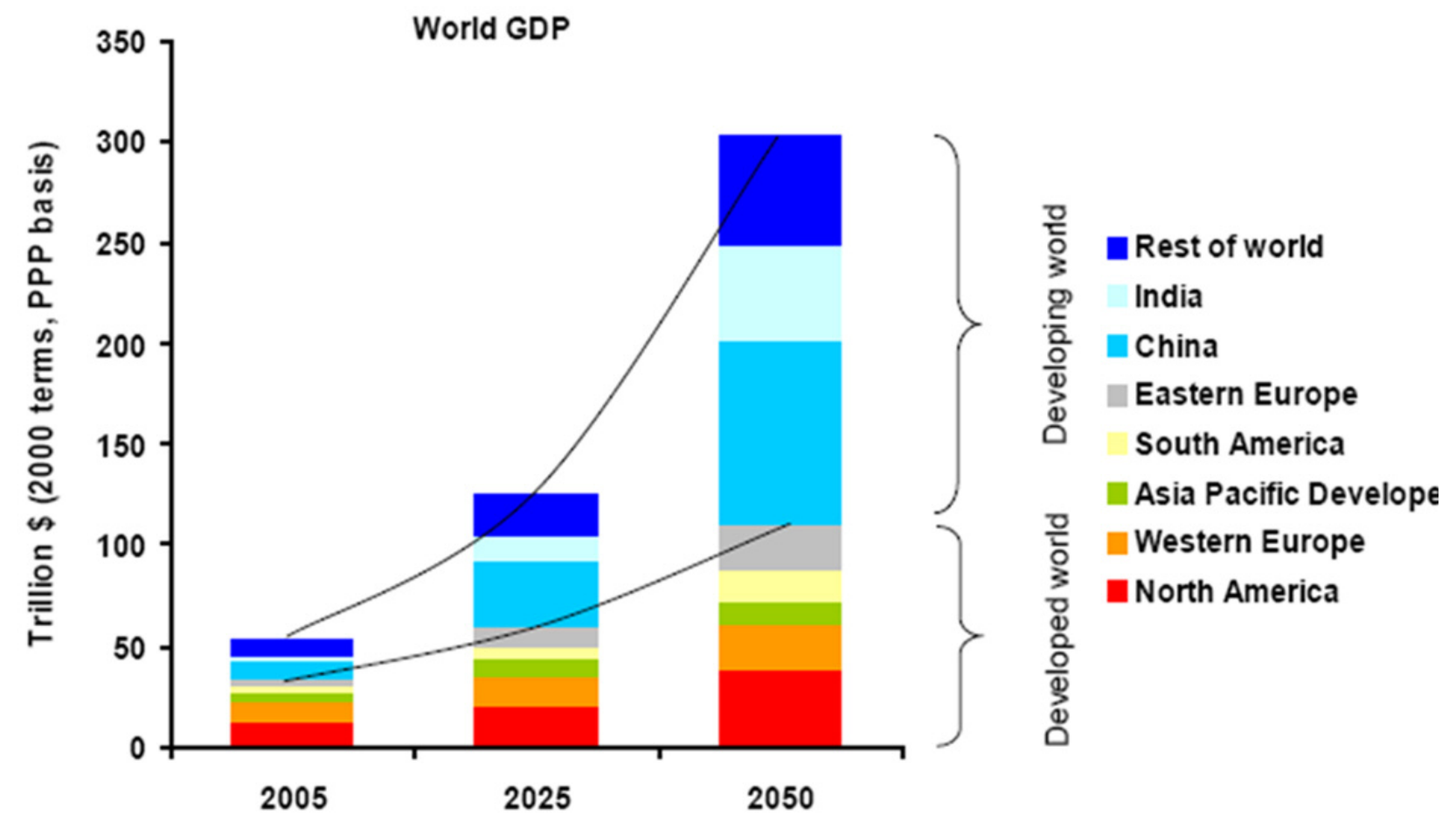

Source: World Bank for base 2005 data; Global insight for growth estimates to 2025; Rio Tinto estimates for 2050 data

Figure 2. Trends in world GDP.

Figura 2. Tendencias en el producto interior bruto mundial

environmental attitude of the population and the way global economy behaves. All of them play a part in the demand for global raw materials (https://blog. euromonitor.com/2016/12/what-drives-demand-natural-resources.html)

Technological advances have made a clear divide between developing and industrial countries (Fig. 3) in terms of the use of mineral resources. While developing countries increasingly need mining resources to build their infrastructures, cities and industries (ferrous and base metals, and construction materials), industrialized countries are tending to reduce the use of ferrous metals and construction materials as their industries and infrastructures are already well developed, and increase the consumption of high-tech metals in the new technologies that are increasingly being demanded by their citizens.

\section{World mining trends}

As a result of the above juxtaposition of facts and trends, global mining is expected to behave (Fig. 4) with a rising production trend in the six resource rich developing countries, a stable situation in current production leaders (Australia, Canada China and Russia) and a stable drop in the EU. In terms of subsectors (Fig. 5) metal ores will probably grow in volume by $200 \%$, non-metallic minerals by $114 \%$ and fossil fuels by $81 \%$ from $1980-2020$.

But, are we not reaching saturation point for certain commodities? Riotinto thinks that not yet (Fig. 6). According to their study, the demand saturation will not be reached for copper until 2040, for nickel way after 2050, as well as that for titanium oxide, borates and aluminum. It seems that for diamonds the saturation level is probably more in deep time than in human time.

\section{Global exploration trends}

As we are going to deal with exploration costs, we might as well review the situation of global exploration.

Global investment in mining in 2016 was $21 \%$ less than in 2015. The average per company investment was 4,4M\$, the lowest since 2009 (Fig. 7). 


\section{Growing Demand for Earth Resources}

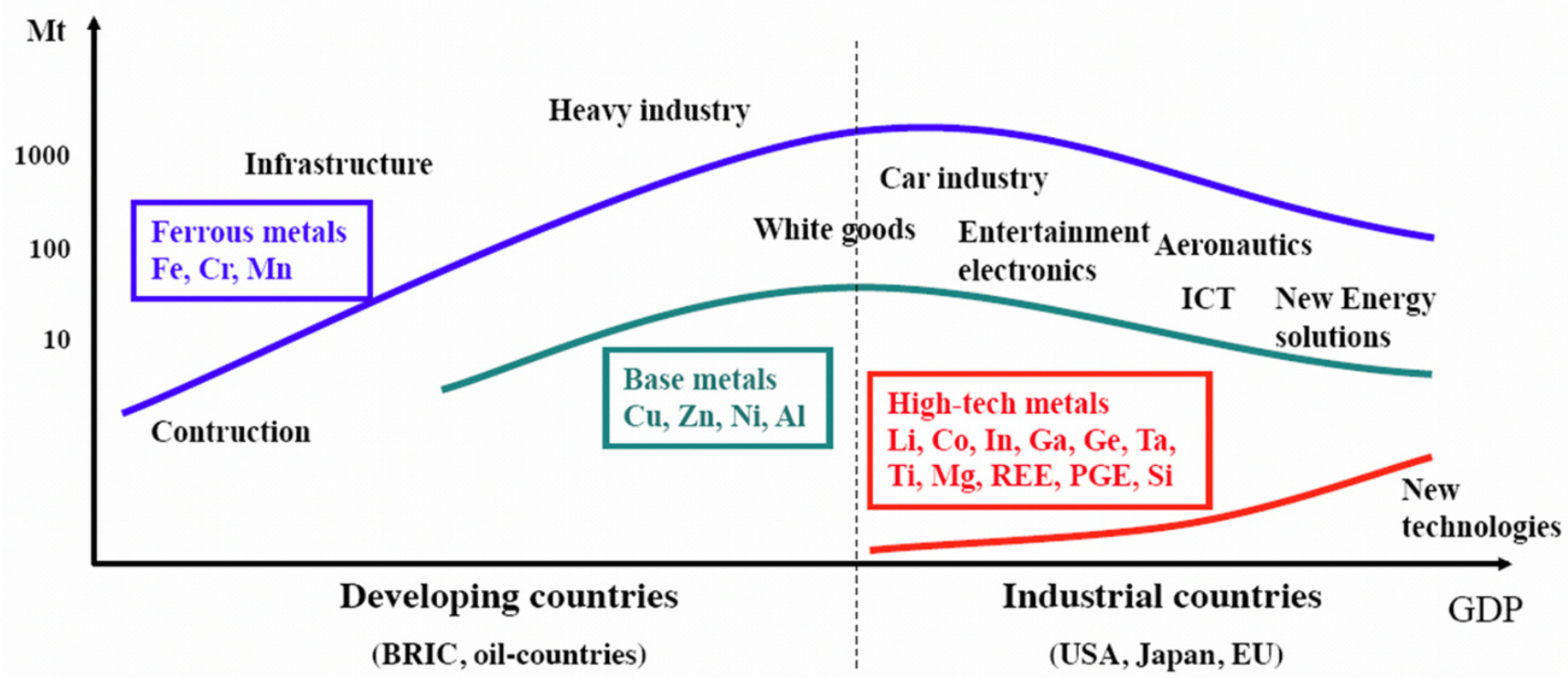

Figure 3. Trends in demand for earth resources by regions.

Figura 3. Tendencias en la demanda de recursos por regiones.

By regions (Fig. 8), Canada and Australia lead the world with $14 \%$ and $13 \%$ respectively. Way below is the United States with 7\% being the third world country in terms of mining investments in 2016. South and North American countries (Mexico, Peru, Chile amongst others) as well as China each represent $6 \%$ of the global mining investment. West Africa, Europe, Russia and Pacific/SE Asia each invest $5 \%$ of the global investment and Brazil and South Africa 4\% each.

According to a 2017 Wood MacKenzie report, global mining expansion capital expenditure (cash expenditure for acquisitions or capital improvements) (Fig. 9) in now increasing from its 2016 low and looks as if it will continue growing in 2018 and 2019. Deloitte ${ }^{1}$ also thinks the cycle has changed and this is the result of a revival in the price of most metals and minerals in an environment of better than expected economic growth. Some surging technological advances have also had something to do with the increasing demand, such as the development of electric vehicles and their batteries. Deloitte believes that 2018 will see a strong economic growth, both because China`s Belt and Road Initiative (BRI) or the Silk Road Economic

https://www2.deloitte.com/content/dam/Deloitte/global/ Documents/Energy-and-Resources/er-mining-capital-projects.pdf
Belt and the 21st-century Maritime Silk Road and the forecasts of the International Monetary Fund (IMF) of a global growth of 3.7 in 2018.

According to a study by Bloomberg ${ }^{2}$, cited by Deloitte (Fig. 10), global mining exploration expenditure will grow steadily over the next 8 years in the favourable environment cited above.

\section{Returns on exploration investment}

Mineral exploration has been traditionally characterized in the economy as a risky business, and returns rarely seem to compensate the costs involved. Nonetheless, mineral exploration is a business activity, and as such it is expected to provide an acceptable return to those who invest in it. Thus investors need such risks involved in mining to be mitigated. According to Singer and Kouda (1999) this can be done by increasing the number of properties examined, focusing on targets with increased probabilities of success, and by incorporating experience and learning.

2 https://www.bloomberg.com/news/articles/2017-03-23/minersregain-mojo-to-spark-18-billion-in-global-exploration 


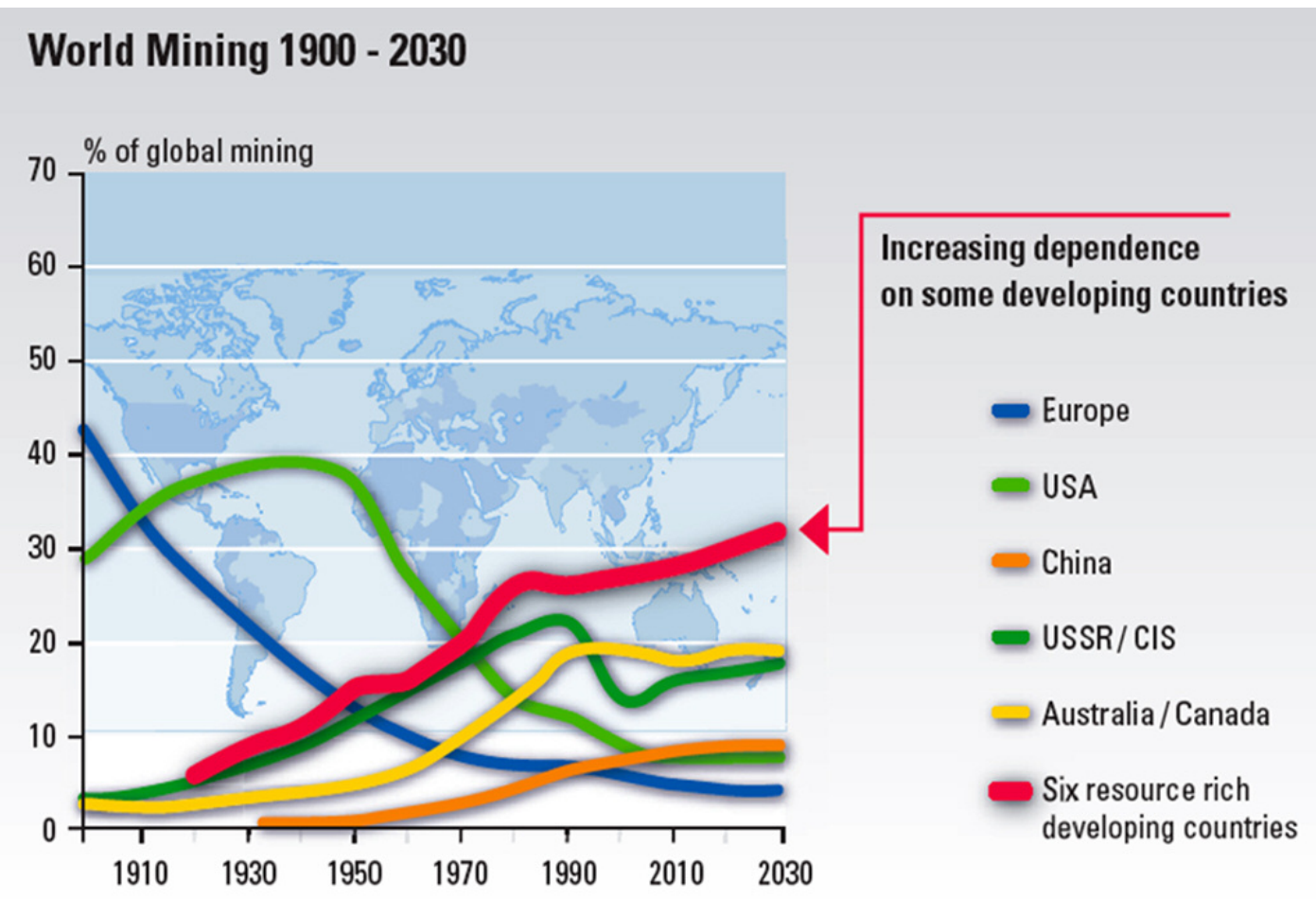

Sources: Ericcson, Raw Materials Data 2005; Sames, 1975

Figure 4. World Mining 1900-2030.

Figura 4. La minería mundial 1900-2030.

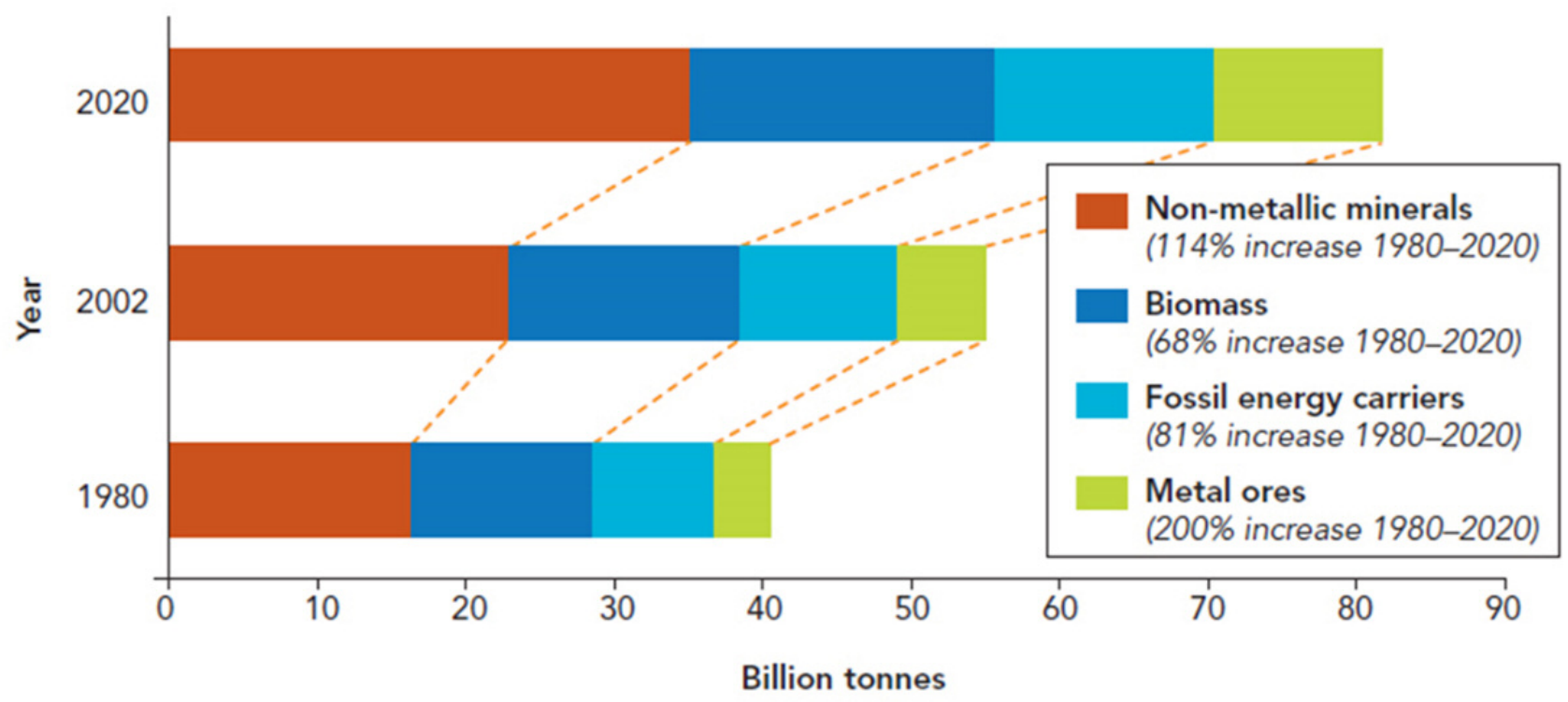

Source: OECD, 2008a

Data based on MOSUS MFA database, Sustainable Europe Research Institute, Vienna, http://materialflows.net; Giljum et al. 2007.

Figure 5. Trends in the mining sub-sectors.

Figura 5. Tendencias en los sub-sectores mineros. 
Inflection point not yet reached for many of our products Percentage of saturation level*

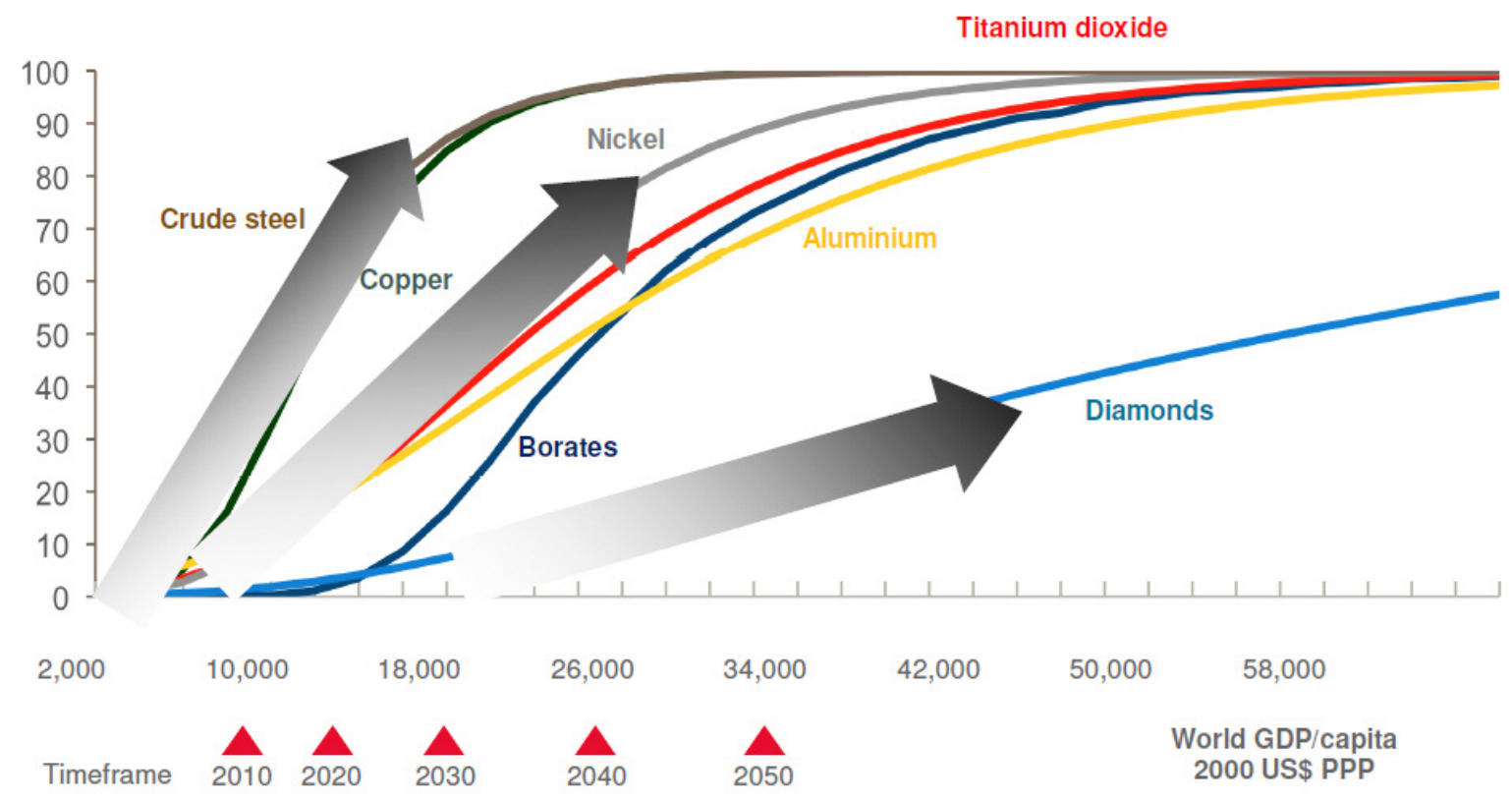

*Saturation level - point at which consumption per capita does not increase with income levels. Source: Rio Tinto

Figure 6. Saturation level of metallic ores.

Figura 6. Nivel de saturación de las menas metálicas.

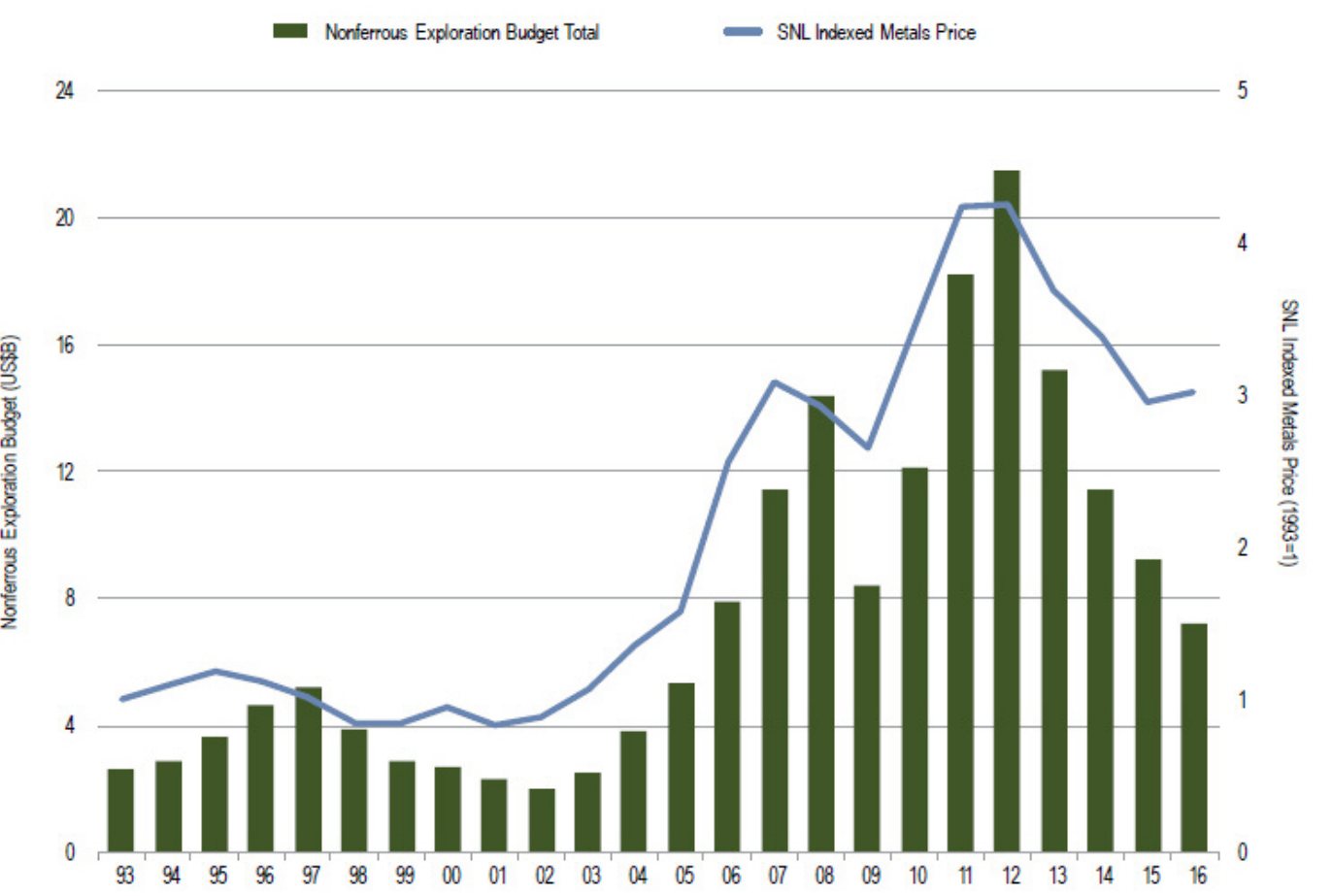

Figure 7. Global mining investment 1993-2016.

Figura 7. Inversiones mineras mundiales 1993-2016. 


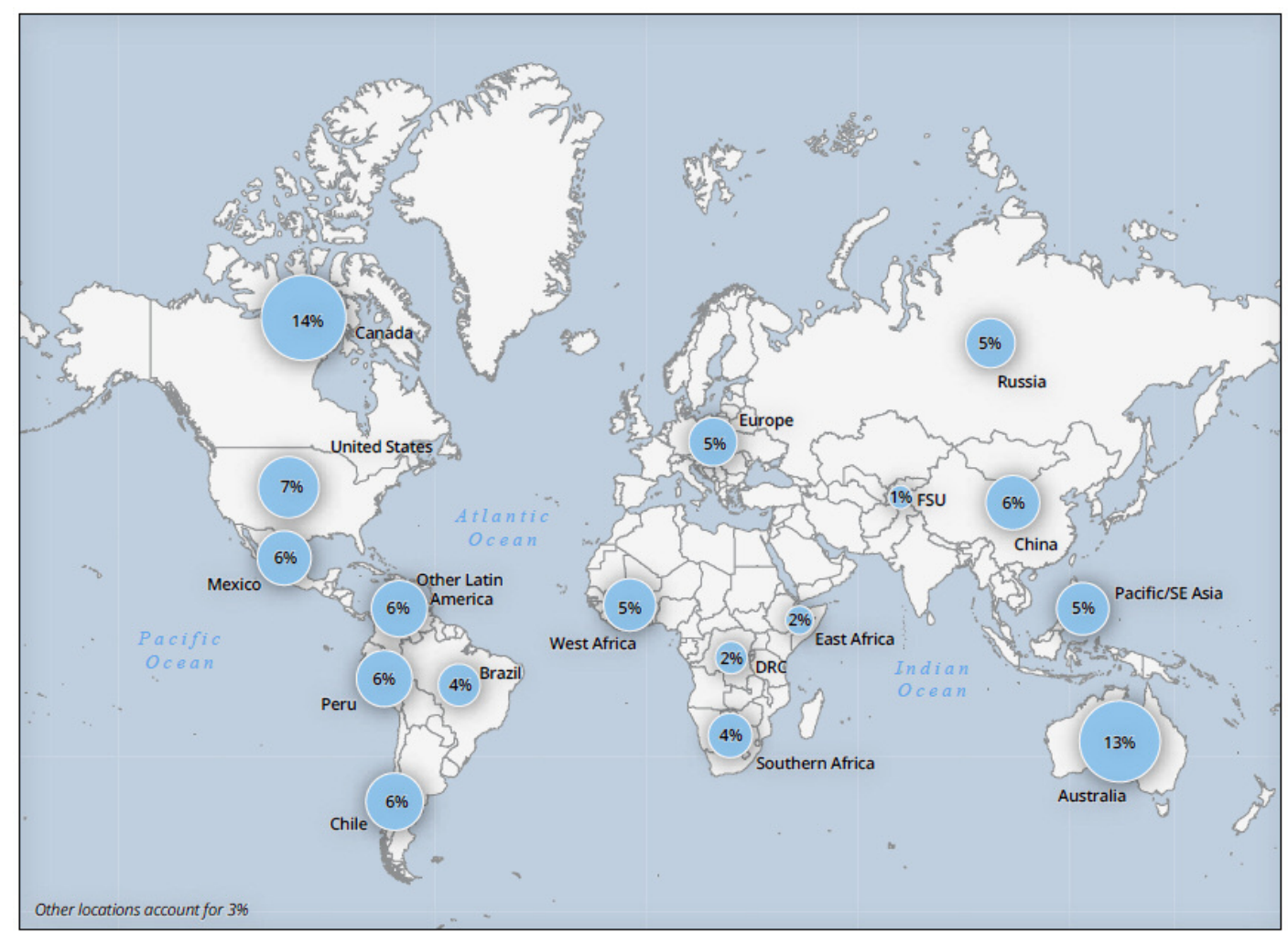

Figure 8. Mining investment by regions 2016.

Figura 8. Inversiones mineras mundiales por regiones en 2016.

\section{Global mining, expansion capex}

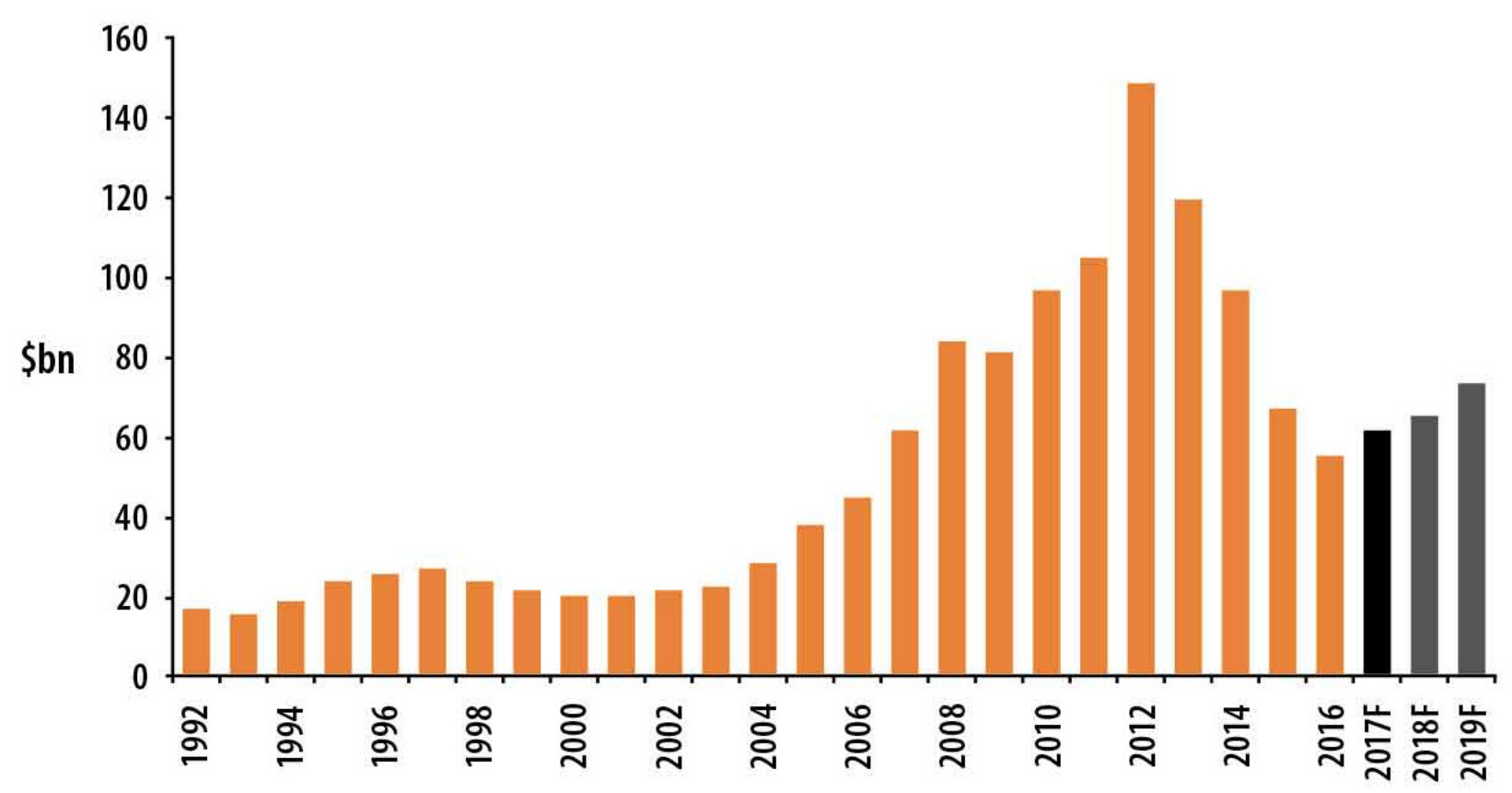

Source: Wood MacKenzie, Macquarie Research, April 2017

Figure 9. Global mining expansion (Capex).

Figura 9. Expansión minera global (Capex). 


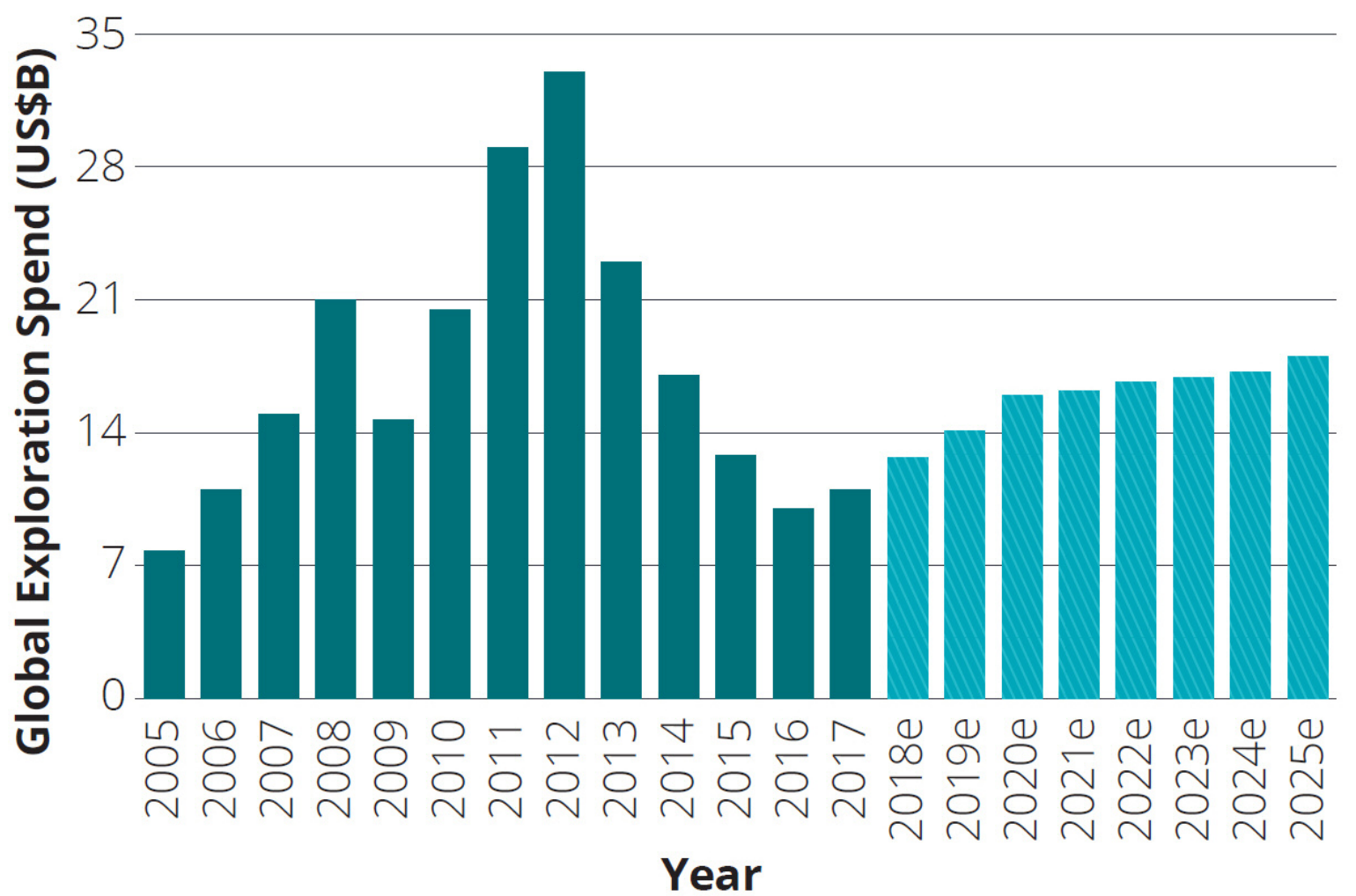

Figure 10. Global mining exploration expenditure trends.

Figura 10. Tendencias en la inversión minera global en exploración.

In a recent study ${ }^{3}$, MinEx Consulting (2013) (Fig. 11) compared mining exploration expenditure in 2012, with the $\mathrm{n}^{\circ}$ of discoveries in tier 1+2 (Net Present Value (NPV) between 250 and 50M\$), and its estimated value. With this information they calculated the rate of value to spend. The results show that the average rate of return on investment in mining and for 2012, is globally less than 1 (that is, a loss) and only Australia (12\%) and Africa (38\%) provide a healthy return on investment.

A stated above, mining exploration at a global scale depends on the changes in the cycles of materials. According to MinEx Consulting the main drivers of exploration are commodity price, availability of funds (in particular for Junior Companies) and long term growth in metal demand, on top of this they also add secondary drivers such as new discoveries, new geological concepts, models and search techniques, new processing technologies (which make lower grade ore bodies economic), government policies and changes

\footnotetext{
3 https://www.minexconsulting.com/publications/R\%20Schodde $\%$ 20 presentation $\% 20$ to\%20CET\%2028\%20Nov\%202013\%20LOW\% 20RES.pdf
}

in business risks (normally related to the country risk).

There are multinational companies, national state owned companies, medium size companies, small firms and junior companies. Each has its own business risk assessment and its own exploration drivers. In fact, global mining factors almost affect instantly junior companies and small firms, and in broad terms, multinationals keep on exploring when the cycle is down (although they also reduce their expenditure).

\section{Return on investment (ROI)}

Return on investment (ROI) is theoretically a simple calculation for any investor: divide the benefit (or return) of an investment by its cost, and express the result as a percentage. Giving the reality that mining is normally a longer-term investment, the ROI can be discounted and the time value of money has to be taken into consideration.

In this regard, it seems that due to the difficulty in establishing such a return in the case of mining, its 


\begin{tabular}{|c|c|c|c|c|c|c|c|c|c|}
\hline \multirow{2}{*}{$\begin{array}{l}\text { Region } \\
\text { Australia }\end{array}$} & \multicolumn{2}{|c|}{$\begin{array}{c}\text { Exploration } \\
\text { Spend (2012 \$b) }\end{array}$} & \multicolumn{2}{|c|}{$\begin{array}{c}\text { No of } \\
\text { Discoveries \# }\end{array}$} & \multicolumn{2}{|c|}{$\begin{array}{c}\text { Tier } 1+2 \\
\text { Discoveries }\end{array}$} & \multicolumn{2}{|c|}{$\begin{array}{l}\text { Estimated Value } \\
\qquad \text { (2012 \$b) }\end{array}$} & \multirow{2}{*}{$\begin{array}{c}\text { Value } \\
\text { Spend } \\
1.12\end{array}$} \\
\hline & $\$ 12$ & $10 \%$ & 84 & $15 \%$ & 14 & $17 \%$ & $\$ 13$ & $14 \%$ & \\
\hline Canada & $\$ 21$ & $18 \%$ & 74 & $13 \%$ & 15 & $18 \%$ & $\$ 15$ & $16 \%$ & 0.71 \\
\hline USA & $\$ 9$ & $8 \%$ & 19 & $3 \%$ & 6 & $7 \%$ & $\$ 5$ & $6 \%$ & 0.60 \\
\hline Latin America & $\$ 27$ & $23 \%$ & 133 & $24 \%$ & 15 & $18 \%$ & $\$ 23$ & $24 \%$ & 0.84 \\
\hline Pacific/SE Asia & $\$ 6$ & $5 \%$ & 23 & $4 \%$ & 2 & $2 \%$ & $\$ 4$ & $4 \%$ & 0.63 \\
\hline Africa & $\$ 16$ & $14 \%$ & 124 & $22 \%$ & 20 & $24 \%$ & $\$ 22$ & $24 \%$ & 1.38 \\
\hline W Europe & $\$ 3$ & $3 \%$ & 24 & $4 \%$ & 1 & $1 \%$ & $\$ 1$ & $2 \%$ & 0.48 \\
\hline \multirow[t]{2}{*}{ Rest of World } & $\$ 22$ & $19 \%$ & 78 & $14 \%$ & 11 & $13 \%$ & $\$ 10$ & $11 \%$ & 0.46 \\
\hline & --- & ----- & ----- & ----- & ---- & $+\cdots$ & -.--- & ----- & -..-- \\
\hline TOTAL & $\$ 116$ & $100 \%$ & 559 & $100 \%$ & 86 & $100 \%$ & $\$ 94$ & $100 \%$ & 0.81 \\
\hline
\end{tabular}

Figure 11. Returns on exploration expenditure.

Figura 11. Retornos de la exploración minera.

analysis and study have been traditionally scarce and inconclusive. In 1979 Ball \& Brown established that from 1970 to $1990 \mathrm{ROI}$ in mining was $-1.2 \%$. Schoddle in 2004 and in 2010, pointed that from 1985 to 2003 the ROI in metal mining was $\$ 1.02$ for every $\$ 1$ spent, and from 2003-2013, for a total exploration expenditure of $\$ 116 \mathrm{bn}$, the added value was $\$ 94 \mathrm{~b}$, that is $\$ 0.81$ for every $\$ 1$ spent.

Leveille \& Doggett (2006) made a very comprehensive review of ROI in a very specific case. The methodology of this study was basically the estimation of the discount cash flow (DCF) in 65 copper mining projects around the globe from 1992 to 2004, deducting from the results the expenses incurred in the exploration. The total investment in those projects was USM\$24,300, with an average of 202 Mt exploited per project. Due to the diverse circumstances of the various projects the authors have made several assumptions:

- In case several metals were recovered they used the copper equivalent and the prices used were those existing at that production time.

- Greenfield discoveries costs included all the exploration costs and also a feasibility study, such as was necessary to estimate proven and probable minable reserves. Brownfield exploration costs were assumed to be related to deposits already in production and were ignored.

- Projects were grouped by deposit typology (porphyry, sediment hosted, IOCG, VMS).

- Internal rate of return (IRR) and net present value (NPV) of the projects were calculated in the periods considered and with discount rates of $8 \%, 10 \%$ and $12 \%$.

- All exploration expenditures have been calculated for tax purposes.

- Based on sample deposits in their database, the average time for a discovery to be made and brought to the stage of positive feasibility was 12 years.

Their results showed that only 17 deposits (of 65 developed, or $26 \%$ ) generated model returns large enough to cover the average discovery costs in the 1992 to 2004 period. The median rate of return to development of the 17 deposits with positive returns to exploration (NPV at $8 \%$ ) was 16 percent. The average of returns of mining exploration which lead to a 
discovery is only positive when a discount rate of $8 \%$ is applied. $77 \%$ of the projects studied returned the capital invested, but only a few of them were able to return the investment when the costs incurred in the discovery are applied (Table 1).

\begin{tabular}{|l|l|l|l|}
\hline \multicolumn{4}{|c|}{ Returns to exploration over the period 1992-2004 } \\
& \multicolumn{3}{|c|}{ Returns to Exploration: NPV mill \$ } \\
\hline Discount rate & $\mathbf{8} \%$ & $10 \%$ & $\mathbf{1 2} \%$ \\
\hline World average & 53 & -19 & -78 \\
\hline Chile & 181 & 72 & -12 \\
\hline
\end{tabular}

Table 1. Returns to exploration rate in copper projects over the period 1992-2004. Leveille, R.A, \& Dogget, M.D. (2006).

Tabla 1. Relación entre exploración y retorno en proyectos de cobre entre 1992 y 2004. Leveille, R.A. \& Dogget, M.D. (2006).

But as this seems a bit discouraging, the Northern Mining Journal decided to ask the question "Does mining have an ROI problem?" to a gathering of 10 top mining and financial professionals at a roundtable discussion they hosted in Toronto, sponsored by PwC (the Northern Mining 2016). In the eyes of the respondents, the single worst ROI driver has been: over-optimistic commodity price predictions over the mine's life $(41 \%)$; overestimated capital expenses $(22 \%)$; longer project development time, owing to more regulations and slower permitting (16\%); and new deposits being lower grade and located in remote areas (9\%).

So according to $\mathrm{ROI}$ analysis, it seems as if mining exploration investment is not a particularly good business, then, why year after year a huge amount of money is being used in mining research?

The reasons behind this fact are probably multiple:

- Mineral substances are dissimilar in their market behaviour. Their demand cycles are not even close.

- Investors' interest. Peter Crowson in his splendid analysis of the economy of mining (Crowson, P. 2008) includes a chapter where he explains why mining has periods of high and low investment attraction and although his analysis needs an update for certain ores, his upward cycle, though somehow halted, does not show downwards signs in the short term. Other scarce minerals linked to new energies and the electric vehicle, while with a certain uncertainty, investment attraction in them seems irresistible in the medium term.
- The skill, knowledge, flexibility, perspicacity and opportunity of the research teams, might be behind the discovery of a World Class deposit, which by itself justifies comfortably high exploration investments. We must here highlight the efficiency of some specialized junior companies.

- There is a great strategical difference between "greenfield" and "brownfield" exploration. Greenfield projects with minimal to no previous exploration carry the risk of operating in literally unchartered territory; the available information is typically limited to the structural setting, the local geology and in some cases limited geophysical data and drilling. Exploration teams must rely on the predictions of geological models to locate potential deposits. Whilst a brownfield project can range from the advanced development stage with a known resource to a proven producer, always in the surroundings of existing mining operations. Statistically both types cannot be compared in terms of risks.

Thus exploration strategy is basically a matter of managing risk which also depends on the size and financial capacity of the company. Few international companies can assume the high risk of greenfield exploration even though the potential benefits are proportional to the risks.

\section{Rate of mining succes}

According to Riotinto (2015 Mclntosh, S.) only $0.03 \%$ of the general industrial ideas provide a successful project. This means that only 1 industrial idea out of 3,000 passes to the phase of production. In the case of mining, the Riotinto experience is that less than 0.1 exploration targets get to the development phase out of 100 original targets.

The global annual exploration expenditure of a major mining company ranges from 100 to $200 \mathrm{M} \$$

A number of studies have tried to estimate the success rate of mining exploration. Kreuzer \& Etheridge (2010) estimate, based on figures by Lord et al. (2001), that the success rate in greenfield is 1 in 200 and in brownfields 1 in 20 (Fig. 13).

Bartrop, S B and Guj, P. (2009) (Fig. 14) believe that in a greenfield-type scenario, the probability of a discovery of a major deposit is $0.3 \%$, in a brownfield $5 \%$ and at a mine site $20 \%$.

The uncertainties of such success values include size, target qualities, exploration models, project maturity and the supply and demand for exploration 


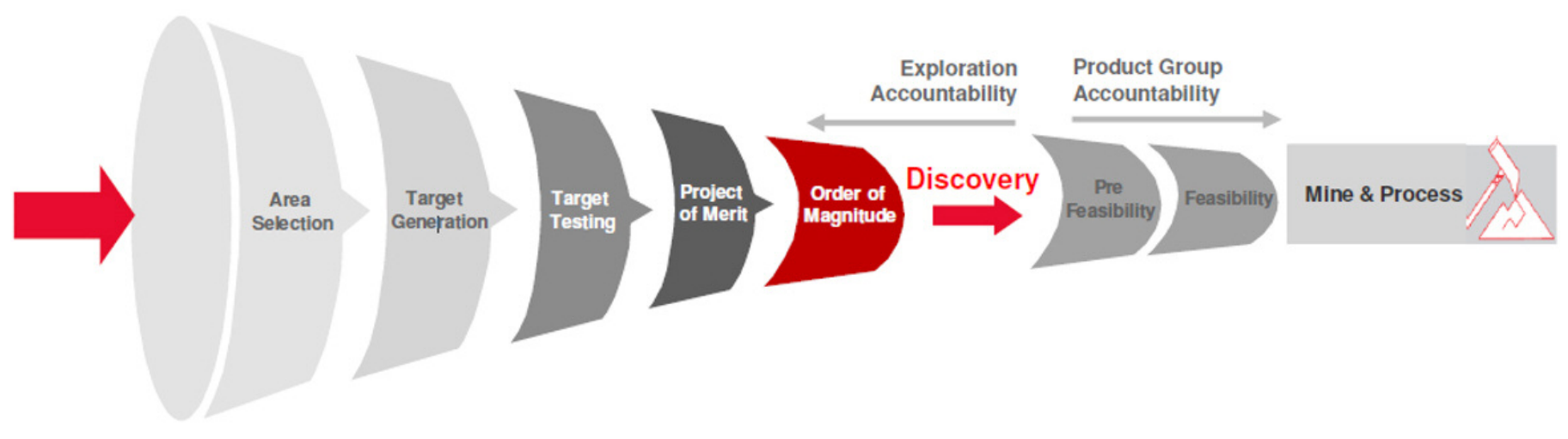

$100 \%$ of targets

- Exploration on an industry-wide basis is a high-risk activity

- Success - the creation of value-demands ongoing rigorous testing and prioritisation of opportunities

\section{$<0.1 \%$ of targets}

- Getting the process right requires technical expertise, high-quality management and rigorous prioritisation

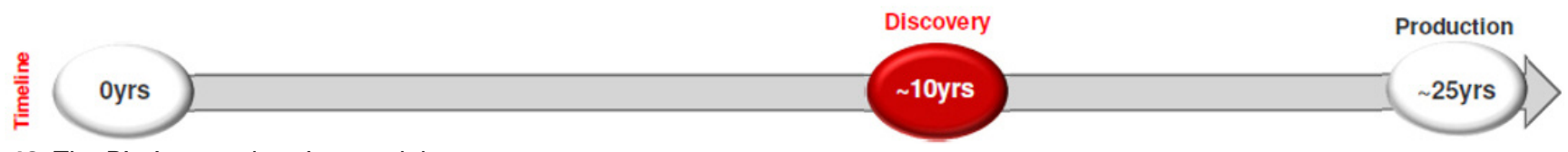

Figure 12. The Riotinto exploration model.

Figura 12. Modelo de exploración de Riotinto.

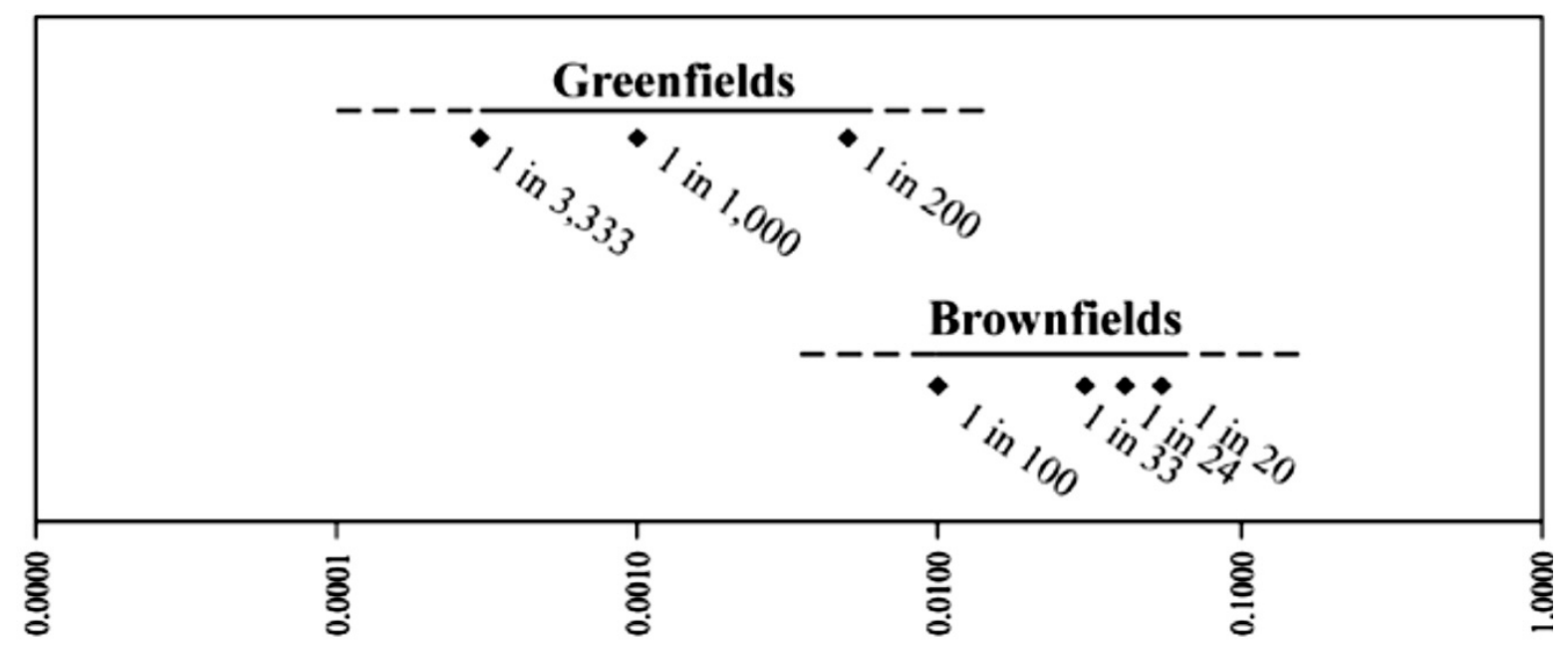

Probability of Success

Figure 13. Probability of success in mining exploration.

Figura 13. Probabilidad de éxito en la exploración minera.

projects. The complexity of these value drivers has resulted in the widespread use of heuristic or rule-ofthumb valuation methods.

In the case of Spanish mining SMEs (annual turnover under US\$ 100M), our experience is that out of 1,000 projects studied, only 100 pass the detailed evaluation, and out of those, only 10 are successful, a rate of success of $0.1 \%$ similar to that indicated by Riotinto.

The level of expenditure in our case is on the range of US\$ 0.5 to $1 \mathrm{M}$ annually, although some SMEs might reach US\$ $5 \mathrm{M}$ per annum. 


\begin{tabular}{|c|c|c|c|c|c|}
\hline Exploration category & $\begin{array}{l}\text { Probability of } \\
\text { discovery \% }\end{array}$ & $\begin{array}{l}\text { Expected } \\
\text { target NPV } \\
\text { Const 2004 } \\
\text { USSM }\end{array}$ & $\begin{array}{l}\text { Probabillty } \\
\text { adjusted } \\
\text { value of } \\
\text { target } \\
\text { Const2004 }\end{array}$ & $\begin{array}{l}\text { Average } \\
\text { cost of } \\
\text { exploration } \\
\text { program } \\
\text { Const. } 2004\end{array}$ & $\begin{array}{l}\text { Expected } \\
\text { value of } \\
\text { exploration } \\
\text { program } \\
\text { Const } 2004\end{array}$ \\
\hline \multirow[t]{4}{*}{ Greenfield } & isajor $0.3 \%$ & 212 & 0.636 & 0.5 & $\begin{array}{l}0.136 \text { plus } \\
\text { value of } \\
\text { smaller } \\
\text { deposits }\end{array}$ \\
\hline & \begin{tabular}{|c|} 
Includes World- \\
class $\mathbf{0 . 0 7 \%}$
\end{tabular} & $\begin{array}{c}\text { Range } 250 \\
2296\end{array}$ & & & \\
\hline & $\begin{array}{c}\text { Minor } \\
\text { discovenes } \\
\text { and above } \\
0.9 \%\end{array}$ & & & & 0454 \\
\hline & & 108 & 0.954 & 05 & \\
\hline Brownfiold & $6 \%$ & 755 & 3775 & 025 & 3525 \\
\hline Minesite & $20 \%$ & $50 \mathrm{OCt}$ & 1.Feb & 0.125 & 0875.1 .750 \\
\hline
\end{tabular}

Figure 14. Probability of a discovery.

Figura 14. Probabilidad de un descubrimiento minero.

Investment in geological exploration and preliminary analysis of the 1,000 projects investigated in detail is estimated between US\$ 10 and $50 \mathrm{M} /$ project/in 10 years (1-5M\$year) this is around US\$100M in preliminary studies. The investment in the 100 projects that pass to detailed evaluation is approximately US\$ $1-2 \mathrm{M} /$ year and in several years, thus a total exploration investment of US\$150M. Furthermore, only 10 projects reach the development phase, an additional investment of US\$ $20-30 \mathrm{M}$ for at least 10 years' research and development is needed, which gives a total investment of approximately US\$250M, meaning US\$25M per successful project.

Considering the fact that US\$100M had been invested in pre-exploration and US\$ $150 \mathrm{M}$ in exploration and feasibility studies (a total of US\$ $250 \mathrm{M}$ ), we should split this among the 10 positive projects, meaning that we must add US\$ 25M to the above expenditure, that is US\$ $50 \mathrm{M}$ per successful project.

One successful project can then have an annual turnover of US\$100M with a potential profit of US\$ $10 \mathrm{M} /$ year, which in 10 years of exploitation would yield a global profit of US\$100M.

To sum up, for each US\$ invested in exploration, and in the case that at least $0.1 \%$ of the initially analyzed projects are successful, we could obtain a return of 2 US\$.

We are obviously excluding the investments in opening a new mine, a new processing plant and the total costs involved in producing a marketable product (OPEX, CAPEX, VAN \& TIR).

\section{Total shareholder return (TSR)}

McKinsey \& Company (2015), in a sound analysis on risk (volatility in theTRS) versus return (annualTRS\%) of capital-intensive industries in different periods, (Fig. 15), points out that from 1973 to 2000 (pre China boom), the TSR was lower than the capital cost and volatility was very high, but from 2001-2011 (China boom), the TSR doubled but the volatility also augmented due to the Chinese super-cycle, and from 2012-2014 the TSR was again down (in the $15 \%$ range) and the volatility was quite high. Despite these cyclic trends, for almost all ores production currently has record figures (copper production has grown $40 \%$ since 2003 , coal $55 \%$ and iron $70 \%$ )

But in this analysis, China, as a huge global mineral consumer, is the main reason for the cycle, so if we study the possible Chinese immediate trends (Fig. 16), an analysis by The Economist Intelligence Unit ${ }^{4}$, shows a slight downward trend of the Chinese economy, from a GDP of $7.4 \%$ in 2014 to $5.6 \%$ in 2019 , now

\footnotetext{
4 http://country.eiu.com/china
} 


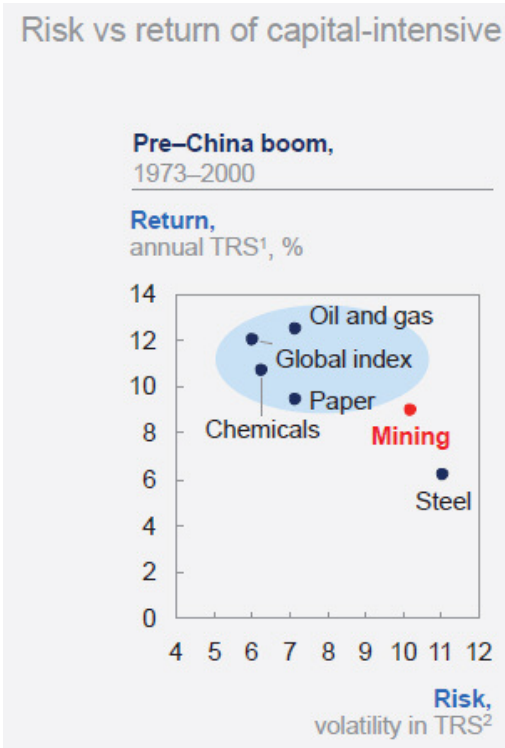

1 Total returns to shareholders.

${ }^{2}$ Average standard deviation of in-year TRS over time period.
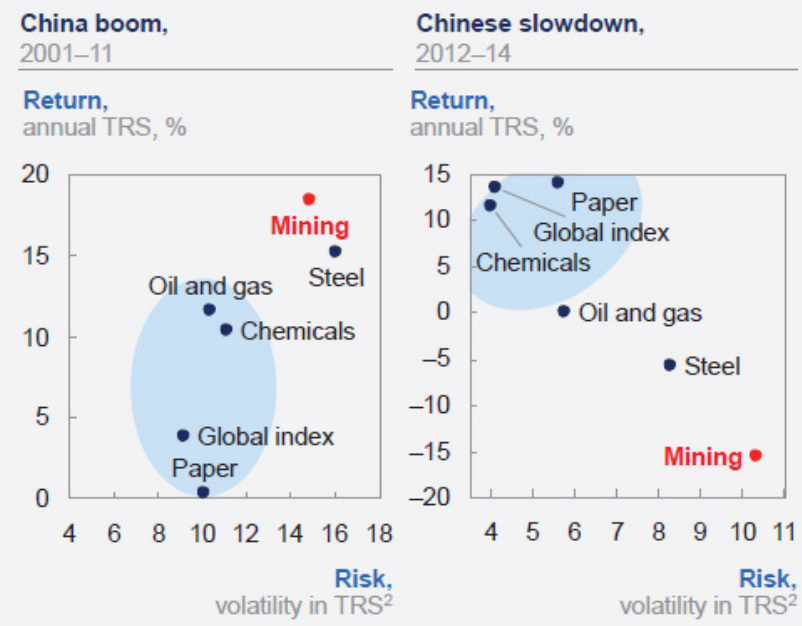

Most other capitalintensive industries

volatility in $\mathrm{TRS}^{2}$

Source: Thomson Reuters Datastream; McKinsey analysis

Figure 15. Risk versus return for capital-intensive industries.

Figura 15. Riesgo frente a retornos en las industrias de capital intensivo.

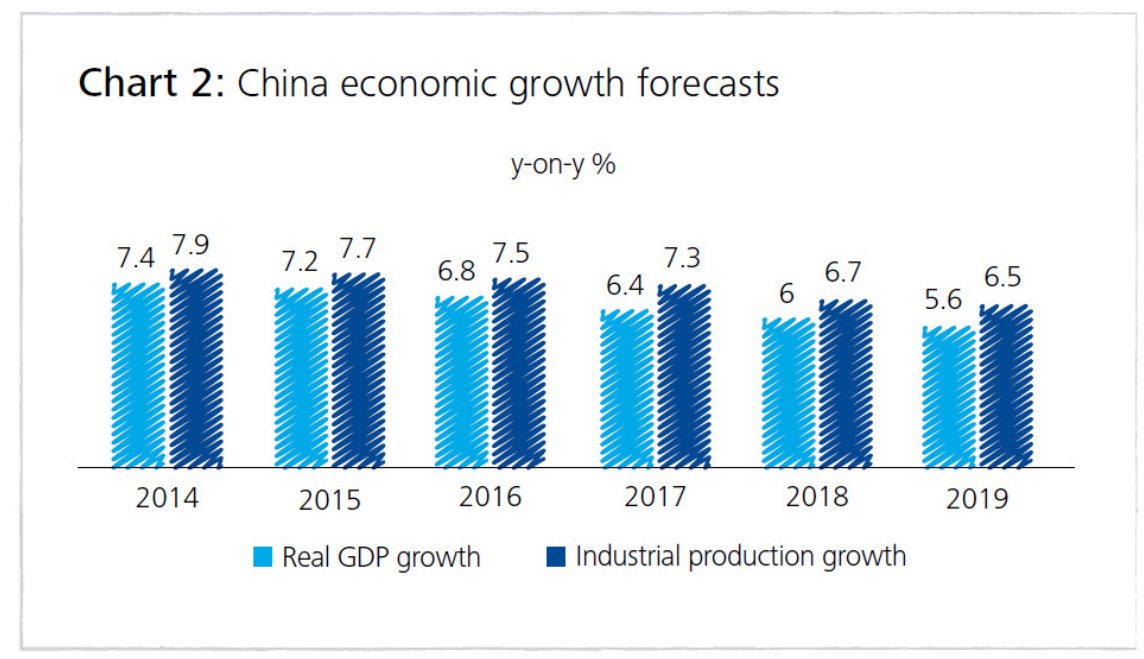

Source: Economist Intelligence Unit forecast database, October 2015

Figure 16. China s economic trends.

Figura 16. Tendencias en el economía China.

revised to $6,2 \%$. All this suggests a stabilization of the Chinese mineral demand in the coming years.

The Boston Consulting Group in its 2011 report "Value Creation in Mining. More than commodity prices" (Fig. 17) analyzed the value creation performance of 37 top mining companies from 1999 to 2009, and showed that the mining and materials sector has created substantial value for shareholders, basically responding to a strong process of commodities in that period (which accounts for half of the TSR in that period). On average, the TSR was $17.2 \%, 9.7 \%$ attributable to price increases. The remaining $7.5 \%$ combine 
volume growth (3.8\%), margin improvements (3.1\%) and dividend yields $(3.1 \%)$. The top ten performers showed an average annual return exceeding 34\%, greatly outperforming their peers.

However, as already mentioned, the total shareholders return is also subjected to mining cycles, and from 2013 to 2016 mining has apparently been a bad business. Figure 18 from Thompson Reuters Data stream, shows the TRS from 2013 to 2016 from several stock markets indexes, $\mathrm{MSCl}$ World Metals \& Mining Index, FTSE 100, S\&P 500 and ASX 200. The mining equities clearly show a marked underperforming trend, with respect to other indexes.

\section{Exploration costs versus resources found}

As shown above, it is very difficult to assess the real return in an exploration investment. Some authors have tried to estimate a direct return on exploration investment indirectly. Philips, G.N. (2013) (Fig. 19) estimated the cost of finding one ounce of gold in Australia by comparing the Australian gold production in different years, the resources found, and the exploration expenditure in different intervals. The results show that in a 25 -year interval, the exploration expenditure was 46.5A per ounce of gold found and in a 9-year interval was $22.8 \mathrm{~A} \$$ per ounce of gold found.

The Australian case cannot be generalized though. In Spain the only gold producer today is Orovalle ${ }^{5}$, which produced around 50,000 ounces of gold last year, but lost $13.23 \mathrm{M} €$ for a turnover of $63.3 \mathrm{M} €$, $17.55 \%$ more than in 2016. Orovalle had an EBITDA in 2017 of $-1.7 \mathrm{M} €$ This points out to high production costs. Production costs are probably the main drawback of gold projects, with a red line in the production costs over $1000 \$$ /ounce.

\section{Profit of mining companies}

Another way of looking at the problem is by studying the accounting of mining companies. After all, nobody would maintain a mining company operating if there was no profit. Figure 20 shows the net profit in billion $\$$ of the main world mining companies. The graph shows net profits from 2002 to 2014 from 6 to a record 132 billion US $\$$ in 2011 , and a net loss of -160 billion US \$ in 2015, and back to profit in 2106.

Apparently, from the company`s perspective min-

5 http://ranking-empresas.eleconomista.es/OROVALLE-MINERALS.html

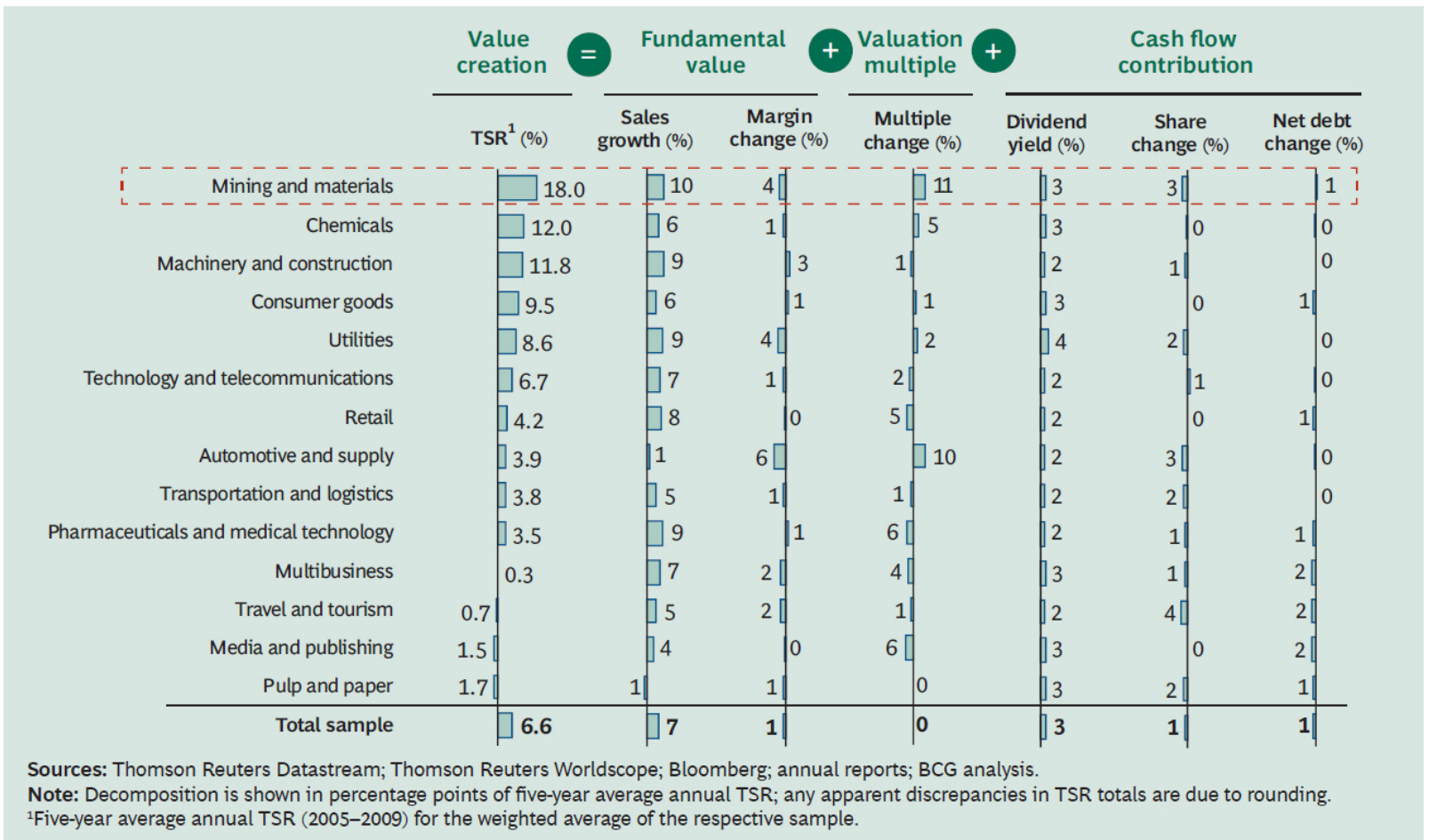

Figure 17. Total shareholder returns on mining investments. Source: Bolton Consulting Group 2011.

Figura 17. Retornos para los accionistas en las inversiones mineras. Fuente: Bolton Consulting Group 2011. 


\section{Mining equities underperform \\ Total Shareholder Returns (TRS)}

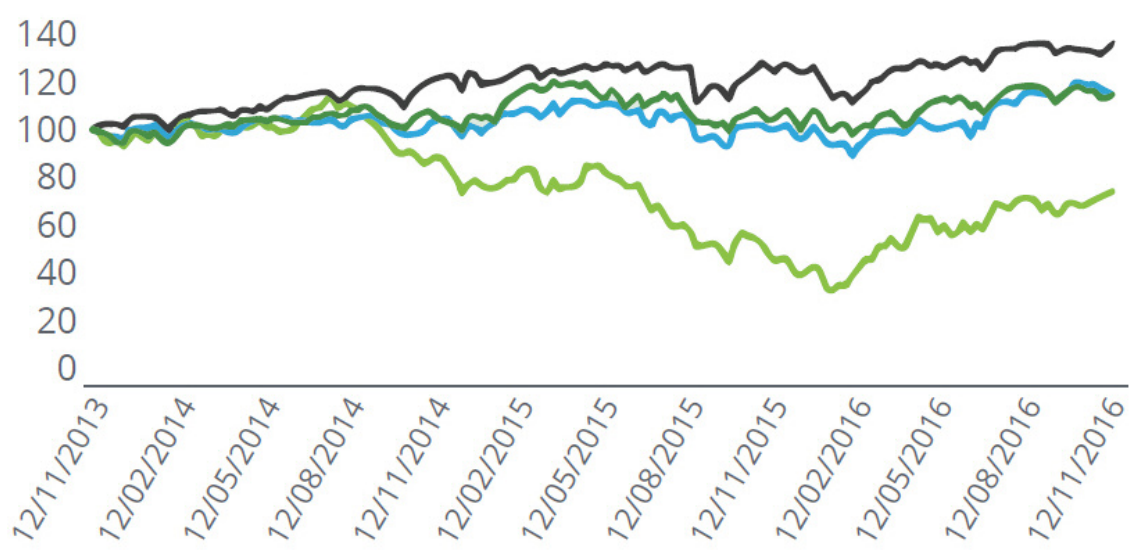

- MSCI World Metals \& Mining Index •FTSE $100 \bullet$ E\&P $500 \bullet A S X 200$

Source: Thomson Reuters Datastream

Figure 18. Total shareholders returns in mining.

Figura 18. Retornos totales para los accionistas en minería.

\begin{tabular}{|c|c|c|c|c|}
\hline a) & 1979 & \multicolumn{2}{|c|}{2004} & 2012 \\
\hline Production $\mathrm{t}$ & 19 & & 258 & 270 \\
\hline EDR (start of year) $t$ & 220 & & 5382 & $\begin{array}{r}9900 \text { end } \\
2012\end{array}$ \\
\hline b) & \multicolumn{2}{|c|}{ 25-year interval } & \multicolumn{2}{|c|}{ 9-year interval } \\
\hline EDR increase $t$ & & 5162 & & 4518 \\
\hline Cumulative gold produced $t$ & & 4575 & & 2241 \\
\hline Gold discovered $t$ & & 9737 & & 6759 \\
\hline $\begin{array}{l}\text { Exploration expenditure } \\
\text { AUD } \$(2012)\end{array}$ & \multicolumn{2}{|c|}{$\$ 14.6$ bn } & \multicolumn{2}{|r|}{$\$ 4.95 \mathrm{bn}$} \\
\hline Exploration cost AUD $\$(2012)$ & \multicolumn{2}{|c|}{$\$ 46.5$ per ounce } & & 8 per ounce \\
\hline
\end{tabular}

Table 1. a) Australian gold production and resources for 1979, for 25 years later in 2004 and nine years later in 2012. b) Measures of gold exploration performance during the 25 year and subsequent nine year intervals using production and added resources as guides. The costs are converted to 2012 Australian dollars and then to ounces for ease of comparing to the gold price. 1 million ounces is equal to 30 tonnes (31.01 t).

Phillips, G.N. Aug. 2013. AusIMM Bulletin, Australian gold exploration - a quick audit (or how do we measure success?)

Figure 19. Costs of finding one ounce of gold in Australia.

Figura 19. Costes de encontrar una onza de oro en Australia.

ing is, in general terms, a very good business. For example, according to the latest Pwc report (Pwc 2018), 2017 was a remarkable year for the top $40 \mathrm{~min}$ ing companies with net profit rising from \$27B in 2016 to $\$ 61 \mathrm{~B}$ in 2017 , thanks to the continuing recovery in commodity prices, fueled by general economic growth. And they also envisage a bright 2018, as global conditions are supposed to be maintained. 


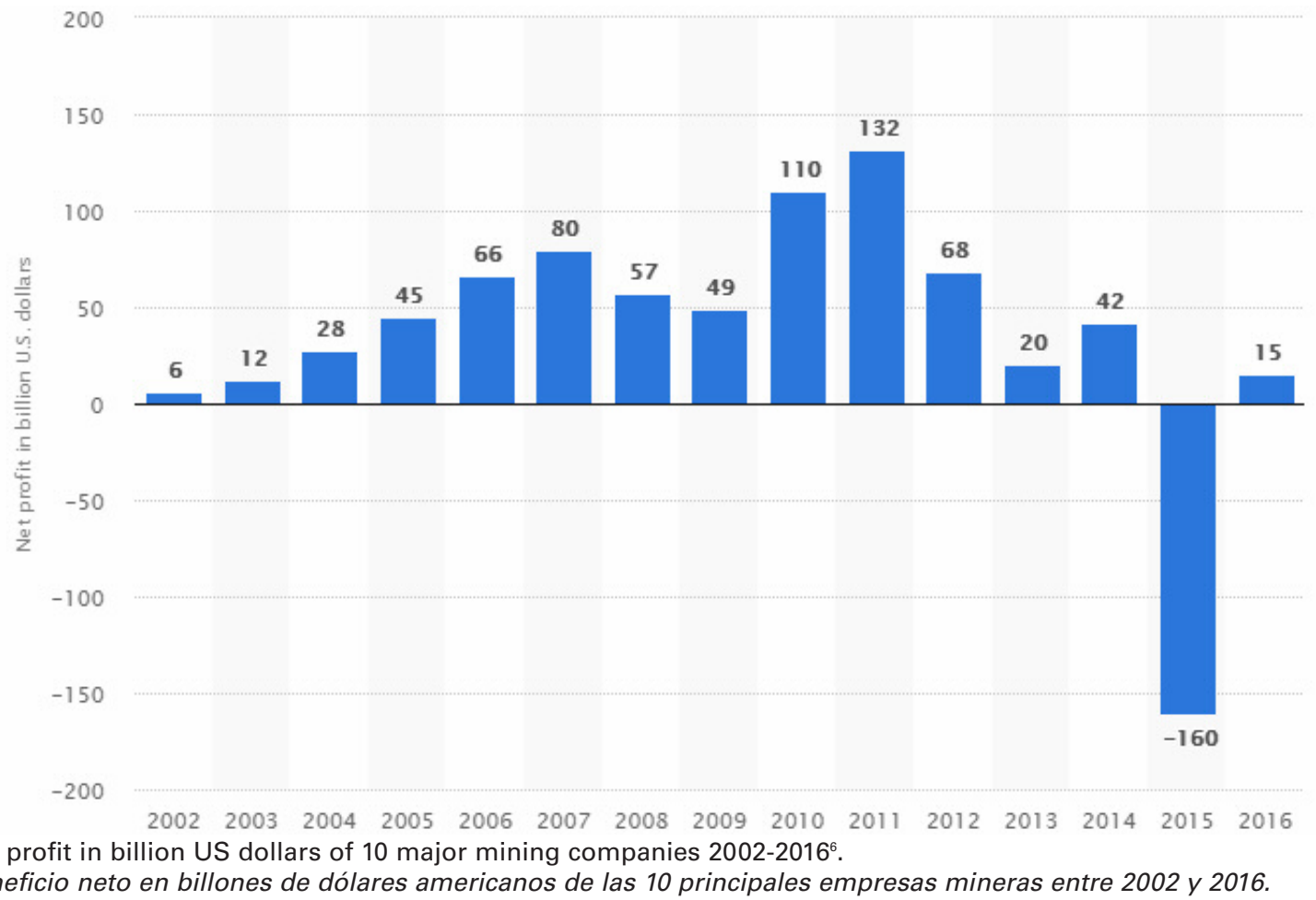

\section{Funds investment in mining}

We should not forget another way of looking at the capital needs of mining: the funds that are invested in mining. Preqin ${ }^{7}$, an assets industry leading source of data and intelligence, reports that overall fundraising for natural resources investment actually declined by a fifth in 2016 to the lowest since 2012 despite the trend reversal of the industry experienced in 2016, being maintained in 2017. Moreover, the Zurich-based Commodity Capital AG, indicates that the mining industry is emerging from a period of cutbacks that while strengthening balance sheets has truncated growth prospects. The Commodity Capital Global Mining Fund (Fig. 21) accumulated returns of 106 percent in 2017, the best performance among 409 commodity-focused funds tracked by Bloomberg.

\section{The mining sector in the future}

Given that mining is a cyclical sector it would be interesting to make an overview its perspectives in the long run. The Mining and Metal Scenarios 2030 is an

\footnotetext{
${ }^{6}$ https://www.statista.com/statistics/208725/net-profit-margin-ofthe-top-mining-companies/

7 https://www.preqin.com/section/overview/0
}

interesting study made in 2010 by McKinsey for the World Economic Forum (https://www.mckinsey.com/ /media/mckinsey/dotcom/client_service/Metals\%20a nd\%20Mining/PDFs/mining_metals_scenarios.aspx)

What will be the health of the mining sector in 2030 ? The study points to the myriad of aspects that will influence mining in the coming decades, grouped by social, technological, economic, environmental and political aspects (Fig. 22). Such a matrix shows how difficult it is to estimate what the future will bring; this is why they use scenarios - "Scenarios are stories about the future. Good scenarios are plausible, challenging and rigorously constructed to address the most critical questions that decision-makers need to face. They represent stories about the future context that are relevant, plausible, challenging and divergent."

The scenarios are based on some certainties and a lot of uncertainties, some of them critical (geo-economic landscape, geopolitical landscape, economic outlook and environmental outlook). Over the course of numerous workshops and interviews, the frameworks were developed into three distinct scenario stories: Green Trade Alliance, Rebased Globalism and Resource Security.

The study goes then from scenarios to strategic options on the part of stakeholders.

Some results of the options derived from the scenarios are: 


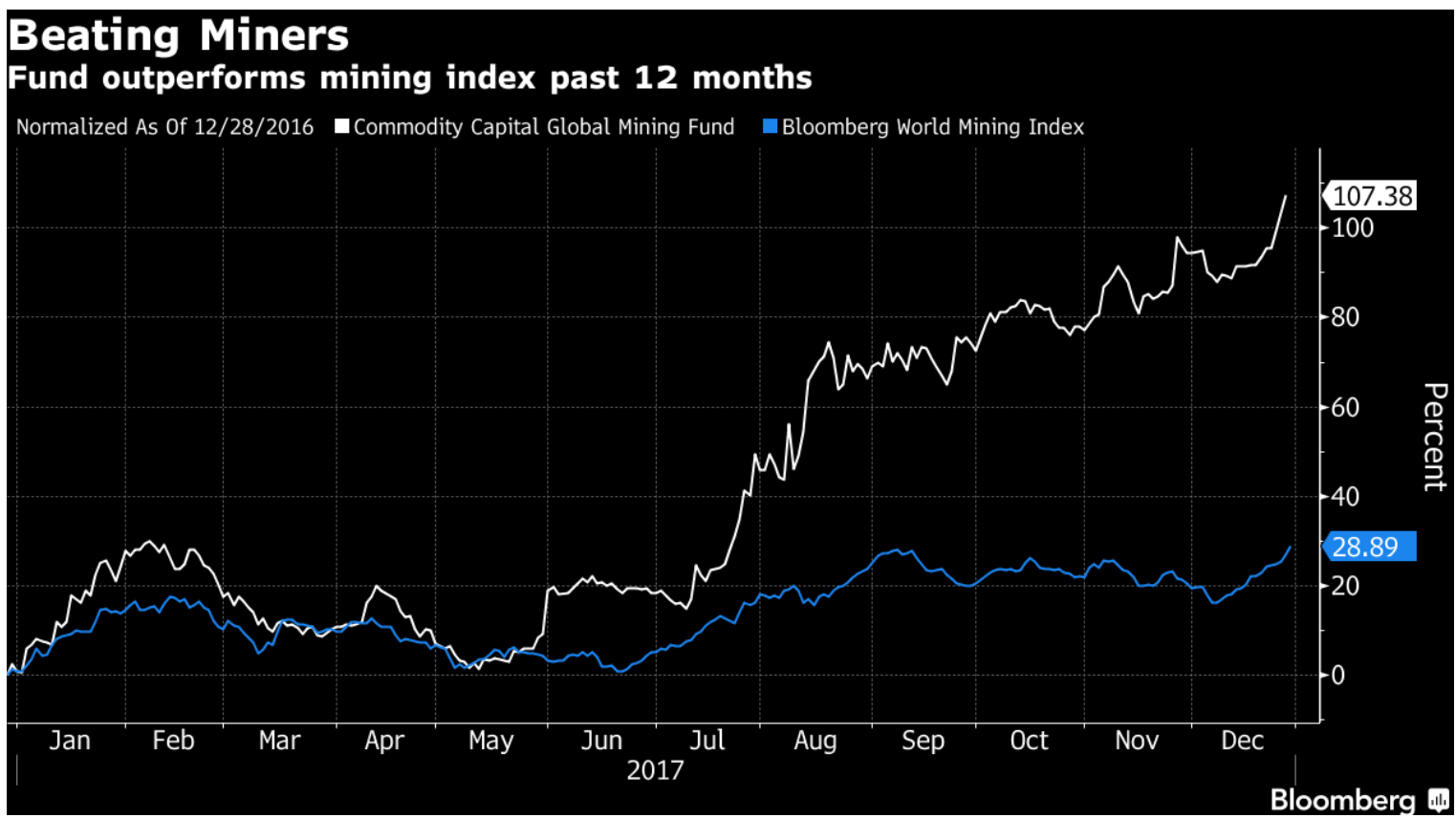

Figure 21. Commodity Capital Global Mining Fund.

Figura 21. Fondo minero Capital Global.

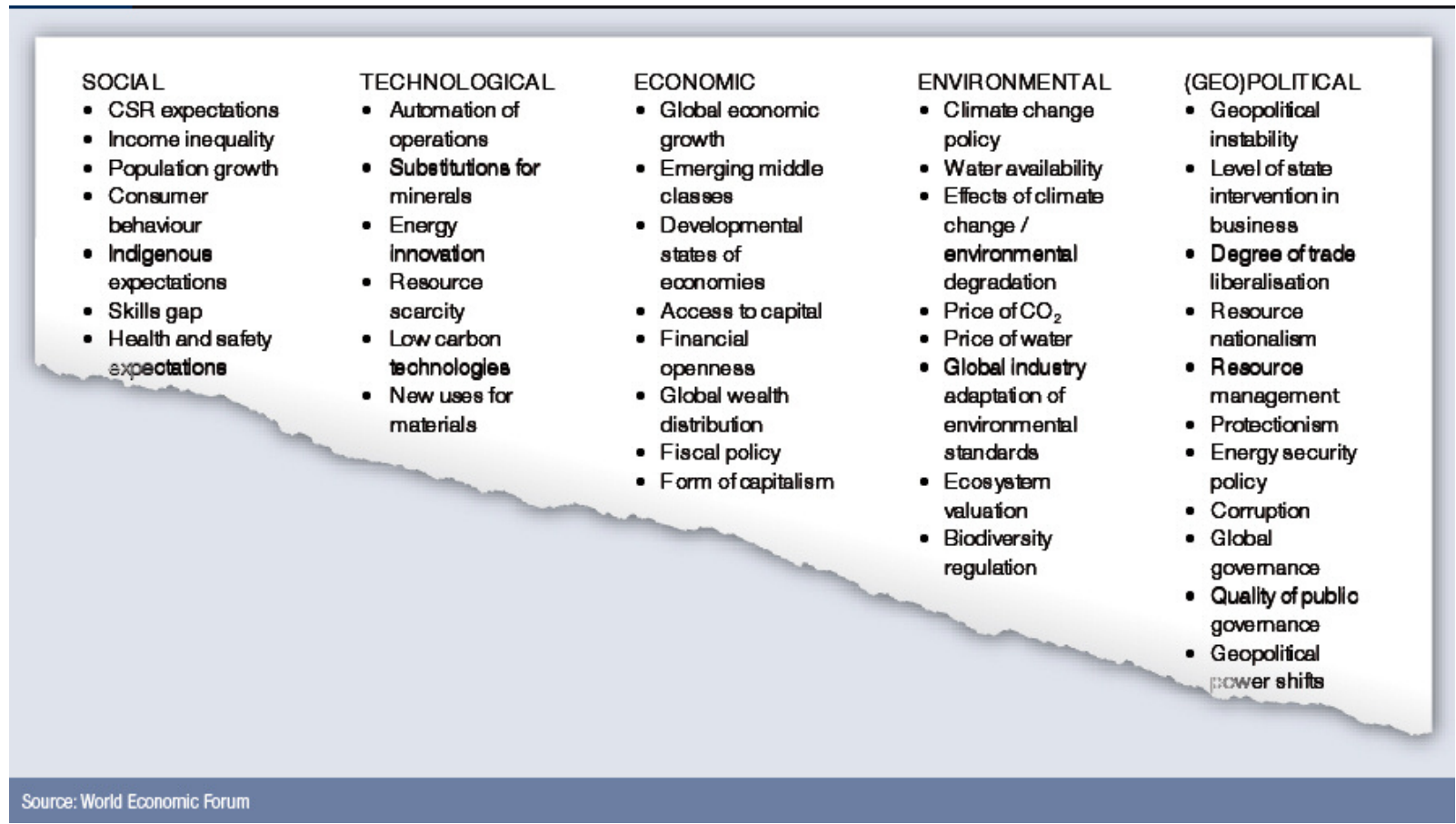

Figure 22. Examples of drivers (non-exhaustive). The Mining and Metal Scenarios 2030. WEF.

Figura 22. Ejemplo (no exhaustivo) de los motores en minería. The Mining and Metals Scenarios 2030. WER.

Green Trade Alliance

- The need to determine the incentives that would entice resource-rich countries to join the GTA

- The need to determine the value of non-
GDP/indirect profits of a sustainable development model

- Within the GTA, resource intensive processes and products need to be reviewed 
- States and businesses need to review value chains as a result of altered trade flows

- The need for mining and metals companies to review their corporate strategies and the implications for organizational structures

- The need to rethink the areas of competitive advantage for mining and metals companies (e.g. exploring life-cycle management)

- The potential for mining and metals companies operating in the non-GTA to dismiss sustainable (environmental, socio-economic, governance) practices

- Technological choices will be determined based on the availability of specific materials.

Rebased Globalism

- Establishment of a "level playing field"

- Blurring of boundaries between the responsibilities of stakeholders

- Longer timeline for resource development due to more in-depth engagement with stakeholders

- Challenge for companies to navigate global and local market conditions simultaneously

- Trade-off between efficiency and social issues (for example, automation versus job creation)

- The need to manage increased operating costs as inputs such as energy and water become more expensive

Resource Security

- Significant substitution of products, minerals, metals and other resources

- Diversification of domestic manufacturing industries

- International mining exploration and operations face economic challenges, bankruptcies, and possible nationalization

- Negative effect on wider economic development due to abandoned mining activities

A later review of their predictions by the WEF (2015) assumed a refined perspective of the scenarios, which are now reduced to three: A world of two speeds, Resource abundance and Global fragmentation.

In these potential scenarios we can still summarize some conclusions for mining in 2050:

- There will be a more sustainable consumption in a more sustainable world.

- Resources will last longer while increased reuse and recycling drive a more circular economy. Such a trend will need appropriate infrastructure, regulation and legislation, and competitive cost economics.
- Mining will not disappear; primary extraction will continue to grow in line with GDP growth. Pressure to realize scale effects and cost efficiency will remain in the foreseeable future together with a strong demand for environmentally and socially responsible actions.

- Metals will not disappear; metals companies will act as a liaison between commodity producers and end industries.

- Technology will be the key, and it will become increasingly important to better understand supply chains and consumer preferences.

\section{Conclusions}

It is clear that the mining industry provides employment and essential materials to any economic and sustainable society and that it is connected to almost all industry value chains. The demand for resources will be driven by the foresighted global economic growth, and the type of resources demanded will depend on the state of the development of the country or region.

To provide the needed resources, exploration must continue globally, but whether such exploration investment is profitable is questionable and we have surveyed the various ways of assessing such profits.

If the returns on exploration investment are analyzed, we can conclude that the average rate of return on investment in mining and for 2012, is globally less than 1 (that is, a loss) and only Australia (12\%) and Africa (38\%) provide a healthy return on investment.

When we use ROI as a guideline, the studies show that from 1970 to $1990 \mathrm{ROI}$ in mining was $-1.2 \%$, from 1985 to $2003 \mathrm{ROI}$ in metal mining was $1.02 \$$ for every $1 \$$ spent, and from 2003-2013, for a total exploration expenditure of $\$ 116 \mathrm{bn}$, the added value was $\$ 94 \mathrm{~b}$, that is $0.81 \$$ for every $\$ 1$ spent. In the particular case of copper mining, the studies indicate that the average of returns of mining exploration leading to a discovery is only positive when a discount rate of $8 \%$ is applied. $77 \%$ of the projects studied returned the capital invested, but only a few of them were able to return the investment when the costs incurred in the discovery are included.

Experts acknowledge these are bad results, and point out that the worst ROI drivers have been: overoptimistic commodity price predictions over the mine's life $(41 \%)$; overestimated capital costs $(22 \%)$; longer project development time, owing to more regulations and slower permitting (16\%); and new deposits being lower grade and located in remote areas (9\%). 
The ROI analysis is probably misleading because mineral substances are dissimilar in their market behaviour, their demand cycles are not even close and mining has periods of high and low investment attraction. The discovery of World Class deposits can turn a bad ROI into an excellent ROI, thanks to the skill, knowledge, flexibility, perspicacity and opportunity of the research teams, and there is a great strategical difference between "greenfield" and "brownfield" exploration, which in turn results in an exploration strategy being really a matter of managing risk.

This highlights the importance of the mining rate of success, and from the analysis we can conclude that the consensus is that the average success rate in greenfield-type scenarios is between 0.5 and $0.1 \%$ and in brownfield is $5 \%$.

If we look at theTSR, we see that on average it was from 1999 to $200917.2 \%, 9.7 \%$ attributable to price increases, but from 2013 to 2016, mining equities clearly showed a marked underperforming trend, with respect to other indexes

If we compare the exploration costs versus the resources found, some particular studies in gold in Australia show that in a 25-years interval, the exploration expenditure was 46.5A $\$$ per ounce of gold found and in a 9-years interval was 22.8A\$ per ounce of gold found. If we consider that 1 ounce of gold is worth $800 \mathrm{AU} \$$ on average in the last 25 years and $1,300 \mathrm{AU} \$$ in the last 9 years, it looks as if finding gold has been a good business in Australia, as in the rest of the world, but the gold prospector must be careful, as processing costs can dwarf profits or even produce a loss (beware of over US\$ 1000/ounce processing costs projects).

If we look at the profit of the major mining companies, we have seen that the net profit of the main world mining companies from 2002 to 2014 was from 6 to a record 132 US \$ billion (in 2011), but we have also seen a net loss of US $\$-160$ billion in 2015, and back to profit in 2016. This simply shows two things: the cyclical nature of mining, and the great average profits that mining generally generates. Mining investment funds also seem to predict a bright future and believe (and in fact put their money on their bet) that mining is going to go up in the near future.

The mining sector will survive its own cyclical nature and the perspectives for the coming future are that there will be a more sustainable consumption in a more sustainable world, that resources will last longer while increased reuse and recycling drive a more circular economy, provided that the appropriate infrastructure, regulation and legislation, and competitive cost economics are provided.
To sum up it is clear that mining will not disappear and primary extraction will continue to grow in line with GDP growth, but technology will be a key factor in this future, and it will become increasingly important to better understand supply chains and consumer preferences.

\section{References}

Ball, R. Brown, P. 1980. Risk and Return from Equity Investments in the Australian Mining Industry: January 1958 - February 1979. https://doi.org/10.1177/ 031289628000500203. Australian Journal of Management.

Bartrop, S B and Guj, P. 2009. Estimating historical probabilities of discovery in mineral exploration, CET Quarterly News, 8:14-15.

Bell, J.A. \& Guj, P. 2012. Exploration Value Drivers and Methodologies. Project Evaluation Conference / Melbourne, vic, 24 - 25 may 2012.

Cameron, P.D. and Stanley M.C. 2017. Oil, Gas, and Mining. A sourcebook for understanding the extractive industries. ISBN (electronic): 978-0-8213-9961-3 DOI: 10.1596/978-0-8213-9658-2.

Crowson, P. 2008. Mining Unearthed. London. Aspermont UK. 423 pages ISBN: 9780954689339

Kreuzer, O P and Etheridge, M A. 2010. Risk and uncertainty in mineral exploration - Implications for valuing mineral exploration properties, The AIG Quarterly Newsletter, 100:20-27.

Krinks, P. Nieponice, G. King, T. Scheibehenne, V. Vogt, T. 2011. Value Creation in Mining. More than commodity prices. The 2010 Value Creation Report. Bolton Consulting Group. Bcg.com. http://www.pirelli.com/corporate/it/channel/sustainability/files/2011/03/Value_creators.pdf

Leveille, Richards A. \& Doggett, Michael D. 2006. Society of Economic Geology. Special Publication 12, 2006, Wealth Creation in the Minerals Industry: Integrating Science, Business, and Education. ISBN: 978-1-629496-30-6. Pages: 329. Chapter 5. Costs, Risks, and Returns of Copper Exploration: Assessing Trends in Discovery and Maturity with Particular Reference to Chile. pp. 91- 107. ISBN: 978-1-629496-30-6

Lord, D., Etheridge, M.A., Willson, M., Hall, G., and Uttley, P.J. 2001. Measuring exploration success: An alternative to the discovery-cost per-ounce method of quantifying exploration success. Society of Economic Geologists Newsletter, v. 45, p. 1 and 10-16.

Mclntosh, S. 2016. Riotinto Exploration. Citigroup Exploration Conference.

Phillips, G. N. 2004. Australian gold exploration - a quick audit (or how do we measure success?). Aus/MM Bulletin, August 2013, 22-23, 25.

Prize Waterhouse. 2018. "Mine 2018. Tempting times". https://www.pwc.com/mining

Schodde, R. 2013. The impact of commodity prices and other factors on the level of exploration. Presentation. 
CET Seminar Series. https://www.minexconsulting.com/ publications/R\%20Schodde\%20presentation\%20to\%20C ET\%2028\%20Nov\%202013\%20LOW\%20RES.pdf

Singer, D.A. and Kuda, R. 1999. Examining risk in mineral exploration. Natural Resources Research. V 8. p. 111-122.

World Economic Forum in collaboration with the International Finance Corporation and Mckinsey \& Co. 2010. Mining and Metals Scenario 2030. (https://www.mckinsey.com/ /media/mckinsey/dotcom/c lient_service/Metals\%20and\%20Mining/PDFs/mining_m etals_scenarios.aspx).

World Economic Forum, in collaboration with Boston Consulting Group. 2015.Mining \& Metals in a Sustainable World 2050. https://www.weforum.org/ press $/ 2015 / 09 /$ mining-and-metals-in-a-sustainableworld-2050-report-launch/

Recibido: diciembre 2017

Revisado: febrero 2018

Aceptado: junio 2018

Publicado: marzo 2019 